\title{
MIGRACIÓN Y CAMBIO SOCIAL EN ANTIOQUIA DURANTE EL SIGLO XIX
}

\author{
Álvaro LóPez TORo * \\ Universidad de los Andes, Bogotá
}

\section{INTRODUCCIÓN}

El proceso del cambio socioeconómico experimentado en Antioquia durante el siglo XIX ha sido tema de interés para muchos científicos sociales extranjeros y colombianos. La renovada preocupación por este problema se explica en buena parte por la curiosidad intelectual que despierta el contraste entre las hondas transformaciones que se registraron en las instituciones y en las actitudes del pueblo antioqueño, por una parte, y la continuidad del régimen latifundista que, heredado de la Colonia, tendió por lo general a intensificarse después de la independencia tanto en otras regiones de Colombia como en muchos países de América Latina, con serios efectos negativos sobre las oportunidades de movilidad social, el aprovechamiento racional de los recursos humanos y naturales y el desarrollo de una genuina clase empresarial.

No obstante, el análisis del caso antioqueño parece haberse resentido de un cierto desdoblamiento en la identificación de los componentes de cambio social. De un lado, algunos autores como Parsons ${ }^{1}$ y Havens ${ }^{2}$ han hecho especial énfasis sobre las características del movimiento colonizador que se extendió hacia el suroeste y el sur de la vieja provincia de Antioquia, en tanto que otros como Hagen ${ }^{3}$ y Saf-

* Este trabajo fue concebido y adelantado aprovechando un período de permanencia en el Office of Population Research de la Universidad de Princeton. Las generosas oportunidades brindadas por esa institución y el constante estímulo de su Director, el profesor Ansley Coale, hicieron posible la realización de este estudio, que resultó además muy beneficiado por los valiosos comentarios y sugerencias de los profesores Arthur Lewis y Mancur Olson, del Departamento de Economía de la misma Universidad.

La redacción inicial del documento fue motivo de reorganización y ampliación ulterior, en desarrollo parcial de las labores de investigación del programa de Demografía del Centro de Estudios sobre Desarrollo Económico, CEDE, de la Universidad de los Andes, Bogotá, programa que está auspiciado y financiado por el Population Council de Nueva York. El intercambio de ideas y las discusiones de trabajo sostenidas con el Director del CEDE, Dr. Francisco J. Ortega, fueron muy provechosas para depurar algunas fallas de argumentación. A pesar de todas estas oportunidades tan favorables, el autor es consciente de defectos significativos que subsisten en el trabajo y cuya responsabilidad a él solo le corresponde.

1 James J. Parsons, La colonización antioqueña en el occidente de Colombia. Versión castellana de Emilio Robledo. Medellín, Imprenta Departamental de Antioquia, 1950.

2 Eugene Havens, Támesis, estructura y cambio. Bogotá, Tercer Mundo, 1966.

3 Everett Hagen, On the Theory of Social Change. Homewood, Illinois, 1962, The Dorsey Press, Inc. Véanse en particular las pp. 353-384. 
ford ${ }^{4}$ han concentrado sus esfuerzos en la interpretación y documentación históricas del proceso de advenimiento del grupo de empresarios mineros, comerciantes e industriales que asumió una posición de liderazgo y una actitud innovadora de decisiva influencia sobre el crecimiento y la transformación de la economía regional. El análisis de la interdependencia entre ambas direcciones del desarrollo económico antioqueño y de su articulación al proceso general de cambio social han merecido mucha menos atención que el estudio parcial de cada uno de aquellos dos aspectos y constituye el objetivo principal del presente ensayo, cuyos lineamientos pueden resumirse en los siguientes términos:

1) Como punto de partida del análisis se identifica el significado de un fenómeno peculiar de la economía colonial antioqueña, consistente en la presencia y evolución de una clase social que, a pesar de carecer de recursos de capital y de tierra, encontró y aprovechó oportunidades de subsistencia económica en actividades independientes relacionadas con la búsqueda de oro, que llegaron a representar una proporción muy elevada de la producción minera de la provincia de Antioquia y ofrecieron una alternativa de ocupación diferente de la de peón o agregado en la hacienda o en la minería de cuadrillas, para una fracción significativa de la población económicamente activa.

2) La influencia de este grupo social dentro de un sistema económico cuyos recursos empresariales y laborales mantenían un alto grado de especialización en la extracción aurífera habría inducido la formación paulatina de una clase mercantil cuya doble función consistía en rescatar una producción metálica dispersa y abastecer un mercado no cautivo de consumidores de víveres, vestido y otros géneros. El desequilibrio crónico entre el crecimiento de los sectores minero y agropecuario habría traído consigo la operación de un mecanismo de desplazamiento del poder económico y político desde la clase latifundista hacia la clase comerciante, que se consolidó al iniciarse la República, pero que previamente encontró su expresión en una crisis profunda de la economía y del régimen colonial de tenencia de tierras.

3) Estas circunstancias parecerian haberse conjugado, de un lado, para presionar un fuerte movimiento de colonización, vitalizado considerablemente por una conspicua aceleración del crecimiento demográfico; $\mathrm{y}$, de otro lado, para ampliar y robustecer el sector de la economía mercantil. No obstante el hecho de que hasta muy avanzado el siglo xIx la articulación de los grupos colonizadores al mercado monetario no parece haber sido muy fuerte, hay alguna evidencia de que los intereses de los colonos y de la alta burguesía de Medellín acusaron un grado significativo de convergencia, de suerte que la política económica y administrativa impuesta desde el centro tuvo una irradiación benéfica en la periferia. En la medida que el lucro capitalista y el bienestar social anduvieron a la par, el control político de la provincia por parte de la clase empresarial habría coadyuvado al notable proceso de mejoramiento del nivel general de vida de la población antioqueña, de ascenso relativo dentro del con-

4 Frank Safford, Significación de los antioqueños en el desarrollo económico antioqueño. Bogotá, Universidad Nacional de Colombia, 1967. 
junto de la economía nacional y de transformación de los estamentos sociales.

4) Las características peculiares del movimiento colonizador y, en especial, la urdimbre de factores económicos e institucionales que condicionaron en buena parte su desarrollo, constituyen igualmente puntos de referencia para evaluar tanto la contribución que el cambio de régi. men agrario representó en la historia económica de Antioquia, como las limitaciones a que estuvo sujeto. En este sentido nuestro análisis trata de enfocar específicamente el papel que jugaron las condiciones de la economía urbana, las modalidades semicolectivistas de la colonización, los choques disruptivos de la política nacional y las modalidades de la actividad económica en la frontera.

5) Este ensayo intenta simplemente ofrecer una interpretación y en cierta medida una sistematización de materiales históricos contenidos en fuentes secundarias. No debe causar sorpresa que una explotación más intensa de archivos y otras fuentes primarias conduzca a una revaluación o a una modificación de las ideas aquí expuestas. Quizá la utilidad de éstas consista en ofrecer hipótesis de trabajo para orientar futuras investigaciones más precisas, aunque ellas conduzcan a conclusiones diferentes.

6) Con estas limitaciones se ofrecen también al final del ensayo algunos comentarios en torno a interpretaciones alternativas del problema, particularmente en cuanto toca a los trabajos de Parsons, Hagen y Havens.

\section{Bases soctales de la minería colonial en ANTIOQuia}

La ocupación del territorio antioqueño por los españoles y la organización social que sucedió al período de la Conquista estuvieron asentadas primordialmente sobre las bases de la actividad minera. Santa $\mathrm{Fe}$ de Antioquia, Santiago de Arma, Cáceres, Zaragoza y Remedios fueron centros urbanos que se desarrollaron en torno a la explotación de ricos yacimientos auríferos como los de Buriticá y Guamocó y de arenas aluviales en los principales ríos de la región, como el Cauca y el Nechí. Hasta mediados del siglo xvir la búsqueda del oro se localizó en un número reducido de minas de alta productividad, con tierras vecinas propicias a las labores agrícolas y con un claro atractivo para el establecimiento de las actividades comerciales. Por fuera de estos centros no hubo hasta entonces ninguna concentración de población que estuviese efectivamente articulada al sistema político colonial. Las pocas reservas indígenas que se constituyeron a iniciativa del oidor Francisco Herrera Campuzano sólo alcanzaron a reunir una población exigua, con pocas posibilidades de desarrollo por la prohibición legal de convivencia con núcleos libres.

Esta naturaleza policéntrica del poblamiento antioqueño inicial estuvo acompañada de condiciones sociales que fueron también peculiares a la época. La institución de la Mita como instrumento inhumano de explotación de los recursos humanos fruto de la Conquista puso de manifiesto el carácter colectivo de la disponibilidad de los factores de producción para los empresarios coloniales y su muy poca preocupación por la conservación de esos recursos, toda vez que esa 
conservación implicaba un costo privado que sólo alcanzaba a reflejarse en un diluido beneficio social. Fue ésta una característica de las reglas del juego económico del conquistador o del noble inmigrante español del primer periodo colonial y que no estuvo presente en las empresas coloniales como la norteamericana, en donde, por ausencia de posibilidades de explotación de una masa esclava, el granjero independiente tuvo acceso a los recursos productivos a base casi exclusiva de su propio esfuerzo. De otro lado, los elevados riesgos de la minería en cuanto a variaciones de la concentración y calidad del mineral, epidemias y condiciones de abastecimiento, han debido contribuir a recortar el horizonte temporal de prospección del concesionario minero $y$, al reforzar su natural avidez de oro, determinar además una alta tasa de sustitución de rendimientos futuros por rendimientos presentes. De ahí, en parte, que el desgaste de los recursos de mano de obra indígena parezca haber sido más intenso en las minas que en las haciendas y que la rebelión de los encomenderos haya podido corregirse más rápidamente que las condiciones de la Mita, que en Antioquia sólo lograron eliminarse setenta años después de haberse expedido las Leyes de la Corona contra el uso de los trabajos forzados de los indios.

La progresiva escasez y el bajo rendimiento de la mano de obra indígena, antes que la vigencia de una legislación protectora, fueron responsables de la introducción de cuadrillas de esclavos negros para el laboreo de las minas, que ya figuraban como una nueva dimensión social del poblamiento antioqueño desde fines del siglo xvi. Aunque de una productividad más alta en el trabajo, estas cuadrillas también fueron víctimas de las epidemias, el hambre y el maltrato de los amos, que posiblemente contribuyó a que se presentaran hacia 1600 una serie de levantamientos, de los cuales quedó un residuo de población negra fugitiva y liberada de la esclavitud. ${ }^{5}$

Negros esclavos y libres, reducidos núcleos indígenas sobrevivientes, un escaso grupo de blancos que dominaban la sociedad, y un creciente número de mestizos y mulatos, componían la población de la provincia cuando a mediados del siglo XvIr esa población no sobrepasaba la cifra de 25000 habitantes. Ésta era la época en que el proceso de mestizaje operaba en la Nueva Granada como el principal factor dinámico de formación de la sociedad colonial. ${ }^{6}$ Lo que es quizás más interesante de subrayar es el hecho de que, mientras en otras regiones granadinas la diferenciación patrimonial, las concesiones territoriales y los privilegios burocráticos contrarrestaron posteriormente los efectos del mestizaje y determinaron una considerable estratificación de la sociedad, los elementos menos privilegiados de la sociedad colonial antioqueña encontraron con frecuencia alternativas de trabajo y de subsistencia que en cierto grado los independizaron del fenómeno de diferenciación de castas, de desvalorización social del mestizo, y de segregación en las instituciones del matrimonio y de la educación.

5 Parsons, op. cit., pp. 52-53.

6 Jaime Jaramillo Uribe, Mestizaje y diferenciación social en el Nuevo Reino de Granada en la segunda mitad del siglo diez y acho. Bogotá, Universidad Nacional de Colombia, 1967. 
En efecto, desde la segunda mital del siglo xvir comienza a presentarse en Antioquia el fenómeno del pequeño minero, del barequero, del mazamorrero, del zambutlidor, del guaquero. Van formándose poco a poco núcleos de gente nómada, buscadores de oro autónomos y aventureros, cuyas actividades sustituyen gradualmente el trabajo de las primeras grandes minas, abandonadas a causa de las dificultades de una tecnología inapropiada para la explotación a largo plazo, ${ }^{7}$ de los pésimos climas y del consiguiente costo excesivo de reposición de las grandes cuadrillas de esclavos, en comparación con su rendimiento. $\mathrm{Al}$ lado de estos grupos independientes operan también empresarios lavadores de oro que van desplazándose hacia las altiplanicies del centro y del oriente de la provincia, donde el clima es más favorable pero se presenta mayor dispersión y menor riqueza de los depósitos auríferos. ${ }^{8}$ Naturalmente, esta circunstancia estimula la minería independiente que se desarrolla en los pequeños aluviones y aventaderos, en los organales, en las sepulturas indígenas y en las proximidades de los yacimientos de los ricos empresarios. ${ }^{9}$ Las condiciones geográficas de la nueva frontera de explotación minera, cuyo suelo quebrado estaba cruzado por un sinnúmero de filones y de aluviones auríferos, plantean así un reto ecológico a un grupo considerable de personas, cuyas oportunidades de empleo estaban antes limitadas al trabajo en la hacienda, o en el gran establecimiento minero, y que ahora encuentran la disyuntiva de una dura brega de aventura, sin la protección del amo pero con las ilusiones de mayor ganancia. La aceptación de ese reto y la consiguiente consolidación de un nuevo estrato social van a tener consecuencias decisivas en las modalidades del desarrollo económico antioqueño.

En primer lugar, la presencia de la clase de mineros autónomos constituye una válvula de escape dentro del rígido mecanismo institucional de la Colonia y en cierta medida contribuye a la formación de una sociedad relativamente abierta, en marcado contraste con otras regiones mineras de la Nueva Granada en donde sigue predominando la mediana o gran explotación, o con las zonas en donde se arraiga el sistema agrario latifundista. Característica del régimen de la hacienda es la manifestación de economías externas que desvalorizan la posibilidad, para un campesino desposeído, de explotar por su cuenta una pequeña parcela independiente, y que cimentan su fidelidad al gran terrateniente. ${ }^{10}$ Al presentarse el fenómeno opuesto en Antioquia, es decir, al ser atractiva la labor del minero libre y al escasear la mano de obra disponible para la explotación del latifundio, comienzan a erosionarse las bases materiales de la gran hacienda.

7 Un ejemplo de estas dificultades era la situación en las minas de veta, en donde los trabajos no podían pasar de cierta profundidad, por la ausencia de facilidades de bombeo y el uso de sistemas muy costosos de desaguie. Ver Vicente Restrepo, Estudio sobre las minas de oro y plata de Colombia, Bogotá, Banco de la República, 1952, pp. 30 y 226.

8 Parsons, op. cit., p. 49.

9 José M. Ots Capdequí, Nuevos aspectos del siglo diez y ocho español en América. Bogotá, Editorial Centro, 1946, p. 125. También Vicente Restrepo, op. cit., pp. 55, 74, 234, 241-245.

10 Celso Furtado, "Amérique Latine - devéloppement et stagnation", en Annales, Economies, Societiés, Civilisations. París, enero-febrero de 1966, pp. 2-8. 
Pero sería una simplificación excesiva explicar la precaria factibilidad del latifundio en Antioquia únicamente en función de la escasez y la inelasticidad de la oferta de mano de obra.11 En las regiones bajas del norte y el oriente de Colombia, por ejemplo, ha subsistido la gran hacienda a pesar de prevalecer una mínima densidad demográfica, en buena parte por las características propias de la ganadería extensiva. Asimismo, en la Argentina del siglo xIX, cuando el ganado salvaje fue desapareciendo y la propiedad rural llegó a ser económicamente significativa por primera vez, la tenencia de la tierra se estableció sobre la base de propiedades hasta de 30000 hectáreas, antes de iniciarse la inmigración europea, y cuando los recursos humanos seguían siendo exiguos. ${ }^{12}$ En realidad, para comprender mejor el fenómeno agrario de Antioquia conviene examinar el extremo opuesto del espectro social propio del latifundio, es decir, las condiciones del propietario.

De un lado, en el proceso de concentración de tierras en unas pocas manos se manifestó en muchas partes de América hispana el poder financiero de la Iglesia. La acumulación de diezmos y la consiguiente influencia sobre el comercio y las finanzas hicieron con frecuencia de esta institución un poderoso agente de control de los recursos líquidos, que facilitaron la compra o el censo de considerables extensiones de tierra. ${ }^{13}$ En este sentido es pertinente observar que la Iglesia en Antioquia era dependiente de las diócesis de Popayán y de Cartagena, a donde fluían hasta el fin del período colonial los diezmos percibidos en la provincia, ${ }^{14}$ lo cual dificultó el florecimiento de los latifundios eclesiásticos. Por otra parte, fue característica propia del orden social latifundista la presencia del terrateniente tradicional, personaje que se distinguía por rasgos propios del rentista sedentario y ocioso, del cacique local o del patriarca benévolo, y una de cuyas principales funciones era velar por el mantenimiento del orden y de la cohesión del grupo semifeudal bajo su dependencia. Los rasgos psicológicos de este personaje se apartaban del carácter inquieto y aventurero del empresario minero, en busca casi permanente de nuevos depósitos auríferos para reemplazar la producción en decadencia de los ya explotados. ${ }^{1.5}$

De allí que el estatuto de concesiones mineras establecido desde 1587 por el gobernador Gaspar de Rodas y que estipulaba títulos individuales de extensión territorial limitada hubiese ejercido una influencia moderadora en el fenómeno de concentración de tierras, que no obstante se manifestó con mucha intensidad en la mayor parte de los

11 Ver, en este sentido, Luis Ospina Vásquez, Industria y protección en Colombia. Bogotá, Editorial Santa Fe, 1955, pp. 13-14. También Luis Eduardo Nieto Arteta, Economía y cultura en la historia de Colombia. Bogotá, Tercer Mundo, 1962, pp. 12-14, 305-308, 322-326.

12 Aldo Ferrer, La economía argentina. México, Fondo de Cultura Económica, 1963, pp. 61-63, 113-115.

13 C. H. Haring, El imperio hispánico en América. Buenos Aires, Ediciones Peuser, 1958, pp. 22 ss. y 310.

14 Ver al respecto Parsons, op. cit., pp. 43, 200.

15 Sobre este aspecto de la sociologia de la hacienda, véase José Medina Echevarría, "A Sociologist's View", en Social Aspects of Economic Development in Latin America, volumen 2, París, Unesco, 1963, pp. 33-39. También, Celso Furtado, Formación económica del Brasil, México, Fondo de Cultura Económica 1962, p. 122. 
valles labrantíos de Medellín, Rionegro y Santa $\mathrm{Fe}$ de Antioquia. ${ }^{16}$ De allí también que en estos sitios se hayan desarrollado simultáneamente explotaciones agrícolas destinadas al abastecimiento de las dispersas localidades mineras y centros urbanos con importantes funciones en el comercio y la administración. En lugar de un esquema administrativo descentralizado en estratos latifundiarios con uno o dos núcleos en donde se asentaba la base del poder político colonial, Antioquia contaría al fin de la Colonia con tres ciudades que competirían en influencia y poder, aparte de no menos de cinco poblaciones de importancia administrativa y comercial secundaria pero real, es decir, que trascendía el papel de apéndice nominal del latifundio. ${ }^{17}$

Movilidad social, debilitamiento del latifundio, dispersión demográfica y diversificación urbana, fueron entonces manifestaciones generales asociadas al florecimiento de la minería independiente, cuando terminó la etapa del poblamiento en un número reducido de centros integrados en torno a los ricos yacimientos de oro. Dentro de este mismo panorama se manifestó asimismo el advenimiento gradual de una nueva clase social, compuesta por un grupo de comerciantes y "rescatantes", importadores e intermediarios entre el agricultor o ganadero y el productor minero. Que estos comerciantes se hayan constituido como un grupo particular puede explicarse como contraparte del acentuado grado de especialización del empresario minero, tanto en lo que respecta a sus recursos de capital como a sus energías de trabajo, solicitados ambos por la continua búsqueda y prospección de nuevos depósitos y por la movilidad geográfica inherente al desplazamiento de los trabajos de uno a otro sitio. Esta movilidad era a su turno la consecuencia natural de las limitaciones tecnológicas de la extracción del oro en una zona geográfica con yacimientos dispersos. ${ }^{18}$ Pero aparte del fenómeno de especialización de los recursos empresariales en la minería, se hizo presente una vulnerabilidad del estrato de mineros independientes a las necesidades de suministro de géneros básicos como vestido, tabaco, cacao, carne, etc., vulnerabilidad que era tanto mayor si se consideran las condiciones de vida nómada en que se desarrollaba su actividad, ${ }^{19}$ y que han debido constituir un poderoso estímulo al desarrollo de las funciones de comercialización o rescate del oro y de abastecimientos a tales grupos productores.

Dentro de este orden de ideas hay que señalar el hecho de que las condiciones en que se movía el comerciante eran bien diferentes de las que prevalecían dentro del sistema de la hacienda, en donde la actividad mercantil se presentaba como un apéndice natural de las rela-

16 Ots Capdequí, Instituciones de gobierno del Nuevo Reino de Granada durante el siglo diez y ocho, Bogotá, Universidad Nacional de Colombia, 1950, pp. 101109. También Parsons, op. cit., p. 5.

17 Medellín, Santa Fe de Antioquia y Rionegro eran las principales ciudades. Arma, Marinilla, Santa Rosa, Yarumal y Zaragoza eran comunidades urbanas menores, próximas a los campamentos mineros. Esta situación sólo parece haber tenido un paralelo en la región de Santander. Véase Jaime Jaramillo, E $l$ pensamiento colombiano en el sigto diez y nueve, Bogotá, Editorial Temis, 1964, p. 143.

18 Condiciones semejantes se dieron durante el siglo diez y ocho en las explotaciones de Minas Gerais, en el Brasil. Véase Celso Furtado, Formación económica del Brasil, pp. 83-84.

19 Ver Vicente Restrepo, op. cit., pp. 74, 234, 244. 
ciones entre el peón feudatario y el terrateniente. A través de bien conocidos mecanismos de venta y de financiación, tales relaciones generaban un mercado cautivo que contribuyó poderosamente a cimentar y a perpetuar la organización social inherente a la estructura agraria tradicional en América Latina. La "tienda de raya", hecha célebre en la literatura de la revolución mexicana. ${ }^{20}$ se presentaba también en las economías mineras que concentraban la mano de obra en unos pocos establecimientos. En donde prevaleció ese tipo de institución, la fácil explotación de las actividades mercantiles aletargó el desarrollo de una mentalidad dinámica y de una especialización genuina por parte de los comerciantes.

Pero tampoco se establecieron en Antioquia las relaciones entre mineros y "rescatantes" de acuerdo con líneas alternativas de adherencia entre unos y otros como las que existieron en Brasil en la era de la colonización cauchera del Amazonas. Allí los productores llegaron a constituirse en los clientes perpetuos de un comerciante que controlaba la tierra pero que se dedicaba más a las tareas de suministro de bienes de subsistencia que a la supervisión de las plantaciones. ${ }^{21}$ En la Antioquia colonial minera no se dio con fuerza ni la tienda de raya, ni la barracão ni la pulpería, ni otra forma de lazo institucional que sujetase el buscador de oro a su abastecedor y lo constituyese en su siervo permanente. Si aquél no encontraba más oro en un determinado sitio, tenía plena libertad de buscar suerte en otra parte, a menudo fuera del área de influencia del rescatante primitivo. ${ }^{22} \mathrm{La}$ desaparición de un cliente implicaba pérdidas de capital para el comerciante, que debía financiarlo en vista del carácter estacional de la minería, así que han tenido que desarrollarse sistemas de selección y compensación de riesgos para asegurar la supervivencia en el negocio. Cuando disminuía la producción de oro y las ropas, que constituían el grueso de la mercancía importada, no encontraban salida natural en el mercado de bienes, se presentaba un riesgo de quiebra porque las facilidades financieras eran limitadas e inelásticas. Puede ayudar a formarse idea del grado de penetración de las actividades del mercader colonial el hecho de que en tales circunstancias, se encontraron sistemas para imponer la ropa no vendida como medio de pago en el mercado de trabajo, hasta representar la mitad de lo devengado por operario de las haciendas, jornaleros y arrieros. En esta forma, la ropa se convertía en circulante subsidiario dentro del mercado de bienes, en el cual regía entonces un sistema dual de precios en oro y precios en ropa, con obvias primas desfavorables para el pago en ropa. ${ }^{23}$

Las actividades del comerciante estuvieron además sujetas a una

20 Nathan L. Whetten, Rural Mexico, Chicago, University of Chicago Press, 1948, pp. 103-107.

"21 Charles Wagley, "The Brazilian Revolution", en Social Change in Latin America Today, Nueva York, Random House, 1960, pp. 184-185.

22 Informe del oidor Mon y Velarde, transcrito por Ots Capdequí, Nuevos Aspectos..., pp. 124-126. En cambio, con el advenimiento de la gran empresa minera e industrial, surgió en épocas posteriores la tendencia a convertir la proveeduria en un instrumento de servilismo laboral reforzado por la ley. Ver a este respecto Alejandro López, Problemas colombianos, Paris, Editorial París América, 1927 , pp. 99-100.

23 Ibid. 
complicación adicional. Hasta poco antes de la Independencia no existieron en la provincia facilidades de fundición de oro ni casa de moneda ${ }^{24}$ y las transacciones se estipulaban en oro en polvo, cuya adulteración era fácil de hacer y difícil de comprobar. A fin de protegerse contra este riesgo el rescatante imponía términos nominales de intercambio muy desfavorable para el minero v nara la comunidad en general. Estos términos sólo mejoraron cuando se inició la acuñación de moneda.

Tales fragmentos de evidencia histórica tienen implicaciones de importancia para nuestro análisis. En medio de condiciones primitivas de mercado, se desarrolló una escuela de disciplina y de entrenamiento en las tácticas y maniobras del mercader competente en su oficio, como también un punto de observación y de control de aspectos críticos del mecanismo social, todo lo cual colocó a los miembros de la fraternidad de comerciantes en una posición favorable para acometer operaciones de amplio alcance cuando se ofrecieron las condiciones propicias, ${ }^{25}$ y para asegurarse el dominio político local al producirse el colapso de la administración española. ${ }^{26}$ En efecto, durante el último período colonial los comerciantes antioqueños controlaban prácticamente todo el oro producido en la región y las autoridades encontraron un medio más eficaz de recaudar el impuesto del quinto real imponiéndolo en cabeza del comerciante, según sus importaciones. Otras piezas del ubicuo sistema fiscal español también dependían del comerciante, como la alcabala, la sisa, etc., en tanto que los diezmos eclesiásticos, como se ha visto, fluían a otras provincias. No resulta así muy aventurada la especulación de que el comerciante, más que el hacendado o el empresario minero, haya adquirido una familiaridad con los asuntos públicos que acrecentó su influencia y su posición social, fenómeno que ha debido reforzarse por la circunstancia de que algunos cargos de la administración pública se otorgaban sobre la base de compensación de servicios pecuniarios. ${ }^{27} \mathrm{Y}$ aunque esos cargos llegaron a ser incompatibles con el ejercicio de la profesión de comerciante, seguían sin embargo disponibles para amigos y parientes de quienes, en ningún caso, han debido estar en posición desfavorable ante otros núcleos citadinos para asegurarse los beneficios que brindaba el control de la burocracia. ${ }^{28}$

\section{Dinamica y CRISis del sistema eConómico colonial}

El proceso de desarrollo económico antioqueño en el período que va desde mediados del siglo xviI (fecha escogida más o menos arbitrariamente para separar la primera y la segunda etapa de la explotación minera) hasta fines del XVIII (época en que la provincia se encuentra sumida en una profunda depresión económica y social que se

24 Ospina Vásquez, op. cit., p. 27.

25 Véase un agudo comentario al respecto, en Ospina Vásquez, ibid., pp. 127-128.

26 Ots Capdequi, Instituciones del Nuevo Reino de Granada..., pp. 364-377.

27 Una descripción de las prácticas abusivas derivadas de esta situación puede encontrarse en la obra de Luis Latorre Mendoza, Historia e historias de Medellín, Medellín, Imprenta Departamental, 1934, pp. 46-47.

28 Vicente Restrepo, op. cit., p. 41. 
trató de remediar a raíz de la visita del oidor Antonio Mon y Velarde) merece estudiarse en algún detalle para comprender mejor los fenómenos sociales y demográficos propios del siglo xIX. En términos simplificados ese proceso puede analizarse en el contexto de un modelo de crecimiento desequilibrado entre dos sectores productivos, de los cuales el minero era el sector líder y el agrícola el atrasado. Las condiciones de rentabilidad y de inversión en ambos sectores dependían, como se verá en seguida, de la estructura social ya analizada, de las relaciones de intercambio de los dos sectores, de las limitaciones de la importación de bienes de subsistencia y de la fuerte posición del grupo comerciante dentro del sistema.

Queda dicho que el sector minero tendía a desarrollarse en dos frentes: el de la minería organizada en los reales de minas y el estrato de mineros autónomos, sin concesiones territoriales, sin cuadrilfas de esclavos y sin más recursos que los medios de trabajo de la unidad familiar. Las condiciones geográficas, la posibilidad de evadir el impuesto del quinto real, las perspectivas de una pequeña empresa independiente, la sencillez de las tareas de lavado del oro y las débiles bases de la sociedad latifundista. han debido ser factores de mucha fuerza para atraer a ese sector una proporción considerable de la población activa. El gobernador Chávez estimaba a mediados del siglo xviII que apenas un tercio de la producción de oro provenía del estrato de minería organizada, ${ }^{29}$ apreciación en la cual concuerda unos decenios más tarde el oidor Mon y Velarde. ${ }^{30}$ El autor Vicente Restrepo llegó a estimar en cinco sextas partes la proporción de inazamorreros libres dentro del total ocupado en la minería y aunque algunos de ellos trabajaban a jornal, la mayoría operaba dentro del sector de minería independiente a juzgar por el informe de Mon y Velarde. ${ }^{2 z}$

En estas condiciones habría algunas bases para presumir que los salarios monetarios en el estrato de la minería organizada tenían un piso dado por la productividad física del trabajador en el estrato de la minería independiente, en vista de la movilidad de la mano de obra de uno a otro sector y del hecho de que el oro era al mismo tiempo el medio circulante. O sea que la minería organizada confrontaba una situación de salarios altos ${ }^{32}$ y de oferta inelástica de brazos, circunstancia que constituía un primer freno a su crecimiento, tanto más poderoso cuanto que la tecnología era rudimentaria, ${ }^{33}$ y no ofrecía posibilidades de inversión en capital físico que elevasen la productividad del trabajador y que redujesen la proporción del costo representada por la remuneración de la mano de obra, ya fuese libre o esclava. No podía esperarse que aparte de la mayor riqueza de los yacimientos de mineral controlados por el empresario minero y de su disponibilidad de esclavos, mediasen factores significativos para elevar los rendimientos económicos muy por encima de los existentes en la minería autónoma. Existían además fenómenos de tipo institucional que ope-

29 Ots Capdequí, Nuevos aspectos..., p. 125.

30 Restrepo, op. cit., p. 51.

31 Ots Capdequí, ibid.

32 Restrepo, ibid., passim.

33 El salario nominal del mazamorrero antioqueño en la época colonial llegó a ser el cuádruplo o más del jornal en las tierras frías de la cordillera oriental. Ver Safford, op. cit., p. 63. 
raron en detrimento de un buen uso del otro factor de producción controlado por el empresario, o sea el de las tierras de realengo concedidas por la Corona. En efecto, en un informe de Mutis y Delhuyar sobre el particular se dejaba constancia de "dos causas esenciales que impedían el progreso de la minería en este Reino: una el corto terreno que conceden las leyes a los Descubridores; otra el que con mala observancia de las leyes, se ha incurrido en el vicio contrario de que al descubridor de un mineral nuevo, por ignorancia de los Jueces y abusos de los poderosos, se le ha amparado en la posesión de enormes extensiones de terrenos". 34 Mediante los beneficios indirectos de la posesión de grandes latifundios inexplotados, algunos empresarios lograban resarcirse de las condiciones económicas desfavorables para la explotación de sus yacimientos. Las grandes concesiones de Quintana en el centro de Antioquia y de Villegas en el sur fueron los ejemplos más conspicuos de esta situación.

Comparando la estructura de la minería al comienzo y al fin de la época estudiada, no queda duda de los cambios sustanciales que experimentó la importancia relativa de cada sector, siendo la tasa secular de crecimiento del estrato autónomo sustancialmente más elevada que la del estrato empresarial. En cuanto al aumento de la producción total, se deduce de los estimados de Restrepo que, mientras en los primeros decenios del siglo XVII podría estimarse en un mínimo de 240000 pesos oro al año, dos siglos más tarde era del orden de 1.0 a 1.2 millones. Si se tiene en cuenta que la población total era a mediados del siglo XviI de 25000 habitantes y en 1808 de 110000,35 podría inferirse que, salvo cambios muy fuertes en la composición ocupacional de la población total, las posibilidades de crecimiento de la producción minera estuvieron determinadas por la tasa de incremento demográfico, en tanto que la productividad de la mano de obra se mantuvo estancada o tendió a disminuir.

Pero hubo además otro serio problema que obró en detrimento de la minería empresarial. Dentro del sistema económico, en su conjunto, predominaba un régimen de trueque de oro en polvo por medios de subsistencia controlados por el sector comerciante en condiciones de semimonopolio que se explicarán más adelante. Llamando $S$ la disponibilidad conjunta de estos bienes de subsistencia (carne, ropas, licores, sal, cacao, etc., y en algunos casos maíz y frijol) en unidades íísicas y $p$ el nivel medio de precios en oro, el comerciante disfrutaba de una posición negociadora muy favorable que le permitía intercambiar el valor $S p$ por una cantidad de oro $X$ igual al total de la producción del estrato minero autónomo, más el valor de los salarios reconocidos por los empresarios a sus dependientes, más la cuota de oro destinada a la subsistencia del propio empresario y sus esclavos. Si se recuerda que casi la totalidad de los costos de producción de la empresa estaba representada por la remuneración de la mano de obra,

34 A propósito de la visita de Mon y Velarde en 1787 a las minas de oro de Antioquia y Chocó. Citado en Ots Capdequí, Instituciones..., pp. 107-108.

35 Vicente Restrepo, op. cit., pp. 38-50. La cifra de producción de oro a comienzos del siglo XviI corresponde al periodo de recuperación de la industria posterior a la gran crisis de fines del siglo anterior, pero anterior a la etapa de las grandes minas de veta. 
$X$ sólo difería de la producción total de oro en la cuantía de las utilidades retenidas por el empresario, más el impuesto proporcional del quinto real. Virtualmente se tenía la ecuación

$$
X=S p
$$

diferenciando con respecto a la variable tiempo, $t$

$$
\frac{d x}{d t}=S \frac{d p}{d t}+p \frac{d S}{d t}
$$

Dividiendo (2) por (1)

$$
\frac{d x}{x d t}=\frac{d S}{S d t}+\frac{d p}{p d t}
$$

O sea que la tasa de deterioro de los términos de intercambio del sector minero, $\frac{d p}{p d t}$ estaba virtualmente dada por la diferencia de crecimiento de la producción minera (a su turno más o menos igual a la tasa de incremento demográfico) y la tasa de incremento de la disponibilidad de bienes de subsistencia..$^{36}$ Siendo la provincia fundamentalmente minera, $X$ debía ser relativamente alto en comparación con $S$, por lo menos en lo que respecta a la parte de bienes producidos internamente. De allí el nivel tan elevado de precios que prevalecía durante la Colonia y que indujo a los intentos de tasación de precios del maíz por parte del cabildo de Medellín a fines del siglo XVIII. ${ }^{37}$ Por otra parte, el crecimiento de las facilidades de intercambio con otras provincias encontraba serios frenos. El ingreso a la fraternidad de los comerciantes importadores era difícil y arriesgado. Los medios de financiamiento eran limitados. Las condiciones de transporte, pésimas, encontraban una complicación mayor debido al monopolio de las bodegas de Nare. Era frecuente la pérdida de cargamentos transportados en mulas y la movilización de la mercancía resultaba lenta y dispendiosa, dada la montañosa topografía y la ausencia de vías naturales navegables. E1 período de rotación del capital se prolongaba aun más por los plazos que debían darse a los mineros. No debían ser muchos los que disponían de los recursos, la energía y la voluntad de mantener líneas estables de intercambio comercial con otras provincias o con España. ${ }^{38}$ Siendo entonces el comercio de importación una actividad semimonopolística, los núcleos de trabajadores mineros se veían forzados a aceptar penosas condiciones de trueque. Lo que ni el terrateniente ni el concesionario de reales de minas pudieron lo-

36 Esta fórmula es obviamente más simple en una economía de trueque monopolístico que en una economía evolucionada. Véase Harry Johnson, International Trade and Economic Growth, Cambridge, Harvard University Press, 1958, pp. $96-110$.

37 Ospina Vásquez, op. cit., pp. 53-54.

38 Véase E. Gómez Barrientos, Don Mariano Ospina y su época, Medellín, 19131918, tomo I, p. 48, en donde apenas se hace mención de una empresa comercial destinada al comercio con el Cauca, hacia fines de la Colonia. 
grar en Antioquia, pudo entonces realizarlo el grupo comerciante, y ello fue, mediante los instrumentos de la compraventa, reducir el nivel de vida del minero libre al mínimo de subsistencia, extrayendo de su producción de oro un considerable excedente de ganancia bruta comercial. ${ }^{39}$

Pero una parte considerable de ese excedente debía dedicarse a reponer las pérdidas de capital circulante, estableciéndose un amplio margen entre el coeficiente bruto y el coeficiente neto de ganancias que, al conjugarse con un largo período de rotación del capital, imponía estrechos límites a la tasa potencial de crecimiento del sector comercial. Estos límites han debido ejercer una restricción al apetito natural del hombre rico por el consumo conspicuo y a mantener viva una tradición puritana muy propicia para el fortalecimiento del espíritu empresarial antioqueño.

En la medida en que el abastecimiento de bienes de subsistencia crecía más lentamente que la población y la producción mineras, se manifestaba una tendencia de alza en los precios que incidía en forma diferencial en desfavor del sector de la minería empresarial, por cuanto la tasa secular de incremento de la producción de oro en este estrato era inferior a la correspondiente en la minería independiente. En otros términos, al subir la producción total de oro ofrecido en trueque a los comerciantes por parte de los mineros autónomos, el precio de los bienes de subsistencia tendía a elevarse. Pero si esa elevación no tenía su contraparte en una mayor extracción de oro por parte de los empresarios, el costo de subsistencia de sus asalariados y esclavos se hacía cada vez más oneroso. En cambio, el trabajador libre contaba con el recurso de incorporar a sus modestas actividades a su esposa y a sus hijos. Las negras zambullidoras trabajaron con vigor y eficacia en las corrientes de los ríos. Familias enteras se dedicaban a la guaquería. ${ }^{40}$

Todas estas circunstancias han debido contribuir a la erosión gradual de la minería esclavista. En efecto, el tránsito de la grande a la pequeña cuadrilla de esclavos ha debido producirse cuando los nuevos yacimientos fueron menos ricos que los viejos ${ }^{41}$ y dejaron de rendir cuantiosas economías de escala. Después, al no haber muchas diferencias entre la productividad física del esclavo y la del minero autónomo, y al quedar ambas absorbidas por el alto costo de las subsistencias, desaparecería el incentivo de adquisición de nuevos esclavos $\mathbf{4 2}$ y surgiría el incentivo de reasignar buena parte de los existentes a las labores de agricultura y de servicio doméstico. Para los empresarios de menor capacidad económica que no contasen con esta alternativa, llegaría el momento en que el alza del nivel de precios colocaría los rendimientos marginales del esclavo por debajo del costo de subsistencia. Fue así como en 1781 un propietario minero de Santa Fe de Antioquia inició el movimiento de liberación de los negros, en abierto

39 Safford, op. cit., p. 65.

40 Vicente Restrepo, op. cit., pp. 233 y 244.

41 Evidencia de este cambio en la riqueza de los reales de minas se encuentra en el citado informe al rey de España presentado por el gobernador de Chávez en 1759, op. cit., p. 30.

42 Parsons, op cit., pp. 53-54. 
acto de rebeldía contra las autoridades coloniales. No podría, pues, interpretarse la posterior iniciativa del gobierno de Antioquia ante el Congreso de Cúcuta (1821) en favor de la política progresiva de libertad de partos, como un simple acto humanitario e idealista. La suerte de la economía esclavista había quedado sellada para una sociedad con un estrato regulador como el de los mineros autónomos y con una excesiva especialización de sus recursos naturales y humanos en la explotación del oro. La única salida que tendría la minería empresarial de Antioquia estaría en la introducción de técnicas y de capital físico que elevasen sustancialmente la productividad del trabajador. El haber percibido esta oportunidad y aceptado el reto de abandonar los trajinados caminos del simple rescate de minerales, constituyó un paso fundamental en el proceso histórico del desarrollo antioqueño, y un testimonio de la capacidad de sus gestores para acomodarse a las nuevas circunstancias de trabajo.

En el análisis del crecimiento desequilibrado se ha ilustrado esquemáticamente el juego de las relaciones entre los dos estratos de la minería, del estancamiento de la productividad, del monopolio del comercio de importación y de las limitantes al crecimiento de la disponibilidad de bienes de subsistencia, a través de ese comercio. Conviene ahora examinar cómo se incorporaba en la dinámica del sistema el factor de producción local, especialmente la agrícola. ${ }^{43}$ En una primera etapa del período parecen haberse dado condiciones favorables para abastecer, desde unos pocos centros agrícolas, las necesidades alimenticias de la población minera que fue dispersándose hacia las laderas y altiplanicies. Las fértiles tierras del valle de Aburrá atrajeron a un número considerable de ricos residentes de Santa $\mathrm{Fe}$ de Antioquia y de emigrantes españoles hacia Medellín, en cuyas vecindades se estableció un número comparativamente grande de haciendas de ganado vacuno, mulas y cultivos de maíz, frijol y hortalizas. ${ }^{44}$ Inicialmente la distribución de la tierra se hizo mediante el mecanismo de concesiones realengas pero posteriormente parece haberse producido un cierto grado de fragmentación de las propiedades a base de ventas, usurpaciones y herencias. Presumiblemente este proceso aceleró la extensión del sector agrícola hasta cuando quedaron controladas todas las tierras disponibles del valle, momento en el cual la inmigración se orientó hacia las tierras de Rionegro y Marinilla.

A comienzos del siglo XVIII se marca así un hito importante en el potencial de crecimiento de la producción alimenticia. De un lado, en esas tierras frías de la nueva frontera sólo era posible obtener una cosecha anual de maíz y de frijol, en lugar de las dos que se daban en tierra templada. De otro lado, las vegas del río Negro, particularmente adecuadas para la cría de ganado, fueron retenidas como ejidos de Santa Fe de Antioquia, provocándose un litigio que se prolongó durante casi un siglo, durante el cual la explotación de esas tierras se hizo mediante contratos limitados de arrendamiento entre los colonos y las autoridades de Santa $\mathrm{Fe}$ de Antioquia. ${ }^{45}$

43 Según Ospina Vásquez, la producción artesanal de lienzos, alpargatas y otras manufacturas fue insignificante durante la colonia; op. cit., pp. 26-27.

44 Parsons, op. cit., pp. 49, 62-63. Restrepo, op. cit., p. 30.

45 Parsons, op. cit., pp. 65-66, 133. 
No disponemos de bases suficientes para determinar en qué medida estos canales institucionales de renta fueron reforzados por el clásico mecanismo ricardiano de la fertilidad diferencial entre la frontera y las haciendas de Medellín y Santa Fe, pero sería poco realista suponer que tal mecanismo haya estado totalmente ausente. Existían posibilidades de que, al aumentar la presión sobre las nuevas tierras, se elevasen los costos de producción y los precios de los alimentos básicos y que los hacendados de tierra templada encontrasen un menor incentivo en incrementar su propia producción al nivel de costo intramarginal que en disfrutar de los beneficios de la renta diferencial por la acción de los nuevos colonos. Algunos hechos históricos podrían aducirse en apoyo de esta hipótesis, que de ser valedera habría tenido serias consecuencias en el orden económico y social. Por una parte, están las célebres comunicaciones de Finestrad, Silvestre y Mon y Velarde sobre la pereza y dejadez que se observaba en muchos círculos de la sociedad antioqueña y sobre la seria escasez de granos que se presentó en la provincia por la "inacción y total abandono con que se ha dejado vivir a cada uno según más le ha agradado". ${ }^{40}$ Por otra parte, y lo que quizá fue más significativo, en la colonización de las tierras de Rionegro y Marinilla se manifestaron importantes fenómenos que bien podrían interpretarse como una reacción enérgica contra esta situación tan desfavorable impuesta por las rentas diferenciales.

Primero, se hizo evidente una preferencia por usos más extensivos de la tierra, tanto en el predominio de la actividad ganadera como en el uso de las técnicas de agricultura de quema. ${ }^{47}$ En ambos casos el mayor coeficiente de tierra por unidad de mano de obra contrarrestaba las desventajas de la fertilidad diferencial. Habiendo partido de una base demográfica insignificante a comienzos del siglo XVIII, cien años más tarde el distrito de Rionegro y Marinilla concentraba más o menos una quinta parte de la población de la provincia y generaba hacia 1780 una suma de diezmos eclesiásticos aproximadamente igual a la de cada uno de los otros dos principales distritos, Medellín y Santa Fe de Antioquia. En la medida incierta en que la comparación de diezmos per capita revele un índice de la situación de productividad agropecuaria, tendríamos que a fines del período colonial ésta sería más del doble en la frontera que en las zonas más fértiles.

Segundo, aunque estos cambios en la asignación de los recursos productivos operaron en beneficio de la agricultura y de la ganadería, el uso intensivo de la tierra tuvo sus límites naturales que, dentro del sistema institucional de tenencia, terminaron por crear fuertes presiones agrarias sentidas con peculiar agudeza en la frontera. Fue de Rionegro y de Marinilla de donde se originó el movimiento de colonización hacia Sonsón, Abejorral y el sur de la provincia.

Tercero, dentro de una economía agraria con tendencias latifundistas y orientada hacia el intercambio comercial, un elevado índice de

46 Mon y Velarde, citado en Ots Capdequí, op. cit., p. 102.

47 Gabriel Henao Mejía, Juan de Dios Aranzazu, Bogotá, Biblioteca de Autores Colombianos, 1953, passim. También Friedrich von Schenck, Viajes por Antioquia en el año 1880. Bogotá, Banco de la República, 1963, p. 18. Además, Parsons, op. cit., p. 133. 
producción de alimentos por hombre significaba la existencia de un correspondiente excedente disponible para el consumo de los terratenientes y sus dependientes, o bien para acometer inversiones en el comercio y en la minería. Ambas actividades ganaron mucha importancia en la frontera del siglo xvirI y fue en sus centros urbanos donde germinó la semilla de lo que más tarde fue el más poderoso grupo empresarial. El comercio trajo utilidades de dentro y de fuera de la provincia. Al terminar el siglo XVIIr el distrito de Rionegro contaba con el mayor número de reales de minas en explotación y Antioquia volvía a estar a la par con el Cauca en producción de oro.

Con todo, el abastecimiento de productos agrícolas necesario para la población del departamento habría estado sometido a restricciones progresivas que conducirían a la honda crisis de antes de fin de siglo. La conducta de los rentistas de Santa Fe de Antioquia y Medellín; la escasez de tierras gradualmente impuesta por las condiciones en los valles de Rionegro y de La Ceja; el efecto de los menores rendimientos por unidad de tierra, y las limitaciones impuestas por la especialización empresarial en los latifundios mineros, han debido confluir en la gran crisis agrícola que a su turno hizo descender radicalmente la producción minera y el comercio organizados. En cuanto al último de los factores mencionados, conviene aclarar que algunos de los terratenientes combinaban la actividad de hacendados y de mineros, pero es de presumir que la búsqueda más o menos continua de nuevos depósitos metálicos y la supervisión de los que estaban en explotación drenaban muy buena parte de su capacidad empresarial. Después de todo, no se administra una hacienda en la misma forma en que se acomete una explotación minera y la clase especial de talento y actitudes que marcan el éxito en la última conllevan cierta incompatibilidad con los hábitos más sedentarios del granjero eficiente. En este tipo de inflexibilidad del factor empresarial podría encontrarse buena parte de las causas de la incapacidad de asignación eficiente de los recursos laborales y naturales entre minería y agricultura, dentro del conjunto de la economía, con miras a nivelar los rendimientos marginales en ambas actividades, o por lo menos a corregir la tendencia crónica de desequilibrio sectorial.

Teniendo presente esta compleja red de factores sociales, económicos y tecnológicos, es posible entonces obtener una comprensión razonable de las presiones que se fueron acumulando dentro del sistema regional hasta llegar a forzar la sustitución de los mecanismos institucionales de acceso y de control de la tierra. El enérgico oidor Mon y Velarde propuso soluciones radicales para restaurar el orden social, superar la crisis de altos precios y baja ocupación, estimular y diversificar la producción y amparar nuevas colonizaciones. La más extraordinaria de estas reformas consistió en conceder acceso libre y gratuito a extensiones limitadas de tierras para la fundación de pueblos y de colonias agrícolas en la vecindad de los centros mineros, sin respetar los derechos previos de los terratenientes. Esas concesiones no se hicieron sobre la base de la influencia y de la posición social de los solicitantes, sino que buscaron el estímulo a los granjeros independientes, la movilización de recursos humanos ociosos y el aprove- 
chamiento de energías empresariales latentes. ${ }^{48}$ Es interesante subrayar el hecho de que la reacción inicial a estas reformas por parte de los latifundistas fue muy moderada. Esto sugiere el reducido valor marginal que para ellos representaba efectivamente una tierra desaprovechada del todo. Sólo después de que se fundaron algunas poblaciones, se abrieron caminos de herradura, afluyeron nuevos colonos, se valorizaron las propiedades, aumentó la producción agrícola, disminuyeron los costos de la explotación minera y se generaron múltiples economías externas que beneficiaban a los terratenientes, hubo interés y acción legal establecida por estos últimos para proteger los derechos existentes. 49

Ahora bien, casi todas estas nuevas colonizaciones auspiciadas oficialmente en las postrimerías del siglo xvIrI se dirigieron a la jurisdicción de Santa Rosa de Osos, zona ésta de poblamiento relativamente antiguo. Fue menor la atención prestada al área de frontera de Rionegro, La Ceja y Marinilla, en donde existía mayor dinamismo socioeconómico y en donde las presiones agrarias eran particularmente intensas. Simultáneamente a la acción oficial se generó el primer movimiento espontáneo en un grupo de aventureros marinillos, quienes invadieron los feudos de la célebre concesión Villegas, fundaron la población de Sonsón y desarrollaron una colonia en la que se equilibraron las actividades de minería y agricultura, corrigiéndose así la estructura hipertrofiada del sistema económico tradicional. A petición de los interesados, la Corona Española canceló la parte correspondiente de los derechos de la antigua concesión. El flujo de migrantes se aceleró y en 1808 se demarcaron una nueva colonia y una nueva población en Abejorral, esta vez con el consentimiento explícito de los latifundistas. Evidentemente se consolidaban así precedentes trascendentales de un nuevo régimen agrario de auténtica funcionalidad económica y se trazaba el modelo de emigración que conduciría a Arma, Aguadas, Pácora, Salamina, Aranzazu, Manizales, Pereira, Quindío y Tolima.

\section{CONDiciones INSTITUCiOnales Y ECONómicas DE LA COLONIZACión EN EL SIGLO XIX}

\section{a) Tenencia de la tierra}

Las zonas ocupadas durante el siglo pasado por la ola de migración antioqueña pueden clasificarse en tres categorías: concesiones realengas, colonizaciones capitalistas y baldíos. Las primeras habían sido por lo general otorgadas por la Corona a personas influyentes $\mathrm{y}$, de acuerdo con la tradición legal, implicaban la obligación de morada y labor. Aunque esta obligación no se cumplió en muchos casos, concedió en ocasiones algún grado de libertad a las autoridades locales para resolver litigios entre invasores y propietarios en favor de aquéllos, si esa solución se consideraba ventajosa desde el punto de

48 Un recuento y una evaluación de estas reformas se encuentra en Alejandro López, op. cit., pp. 20-47.

49 Parsons, op. cit., pp. 69-70. 
vista social o político. ${ }^{50}$ Como casi toda la región de la frontera de colonización, estos territorios estaban cubiertos de selva virgen, cuya limpieza solicitaba habitualmente una tarea de tala y quema intensiva en el uso de la mano de obra, ${ }^{51}$ antes de iniciar las labores de cultivo. Al iniciarse la colonización se presentó una variedad de actitudes por parte de los propietarios, usualmente descendientes de los primeros concesionarios, hacia los grupos agresores. Tal como se ilustró al término de la sección anterior, esa actitud llegó a veces a traducirse en una condescendencia inicial y en la entrega de una extensión limitada de terrenos a la primera ola de recién llegados, condicionada a la fundación de un puteblo y a la apertura de fuentes de trabajo en agricultura y en obras públicas. Al intensificarse la atracción migratoria en vista de las condiciones favorables, y al recogerse el fruto de las economías externas creadas por los primeros colonos, la posición del terrateniente comenzaba a hacerse precaria y los costos de protección de sus derechos en cuanto a vigilancia, acción legal y conflicto abierto, dejaban de ser superiores al valor de la tierra adicional amenazada. En ese momento la confrontación entre ambos grupos se hacía más hostil, se manifestaban actos de violencia y se establecían prolongados procesos judiciales al nivel provincial y nacional.52

Sin embargo, para entonces el movimiento había cobrado notorio impulso y su significado social se expresaba dentro de un nuevo contexto de la política local. Al obtenerse la independencia de España, el consiguiente vacío de poder fue colmado en Antioquia por la clase comerciante. Muchos de los gobernadores del período 1820 a 1850 fueron extraídos de la élite de ese grupo, ${ }^{53}$ cuya influencia en los destinos de la provincia era definitiva dadas las tendencias federalistas que prevalecieron durante la primera época de la República. Como algunas de esas personas desarrollaron simultáneamente un interés privado y especulativo en empresas de colonización de tipo capitalista, es explicable que el gobierno local antioqueño haya adoptado una actitud de estímulo y de protección a la colonización en general, que se veía muy presionada por la sustancial aceleración del crecimiento demográfico. Es cierto que en uno de los casos famosos de conflicto, el de la concesión Aranzazu, ${ }^{54}$ se lesionaron los intereses de un terrateniente aristocrático, heredero de un concesionario español, y quien durante algún tiempo fue gobernador de Antioquia y alto funcionario del gobierno nacional. Aunque este caso fue sometido a las autoridades judiciales, el arreglo final favoreció los intereses de los colonos.

Es inconcebible que situaciones como éstas se hubiesen presentado en un país dominado política y socialmente por una clase de terra-

50 Ver Albert O. Hirschman, Journeys Towards Progress. Nueva York, The Twentieth Century Fund, 1963, pp. 98-99.

51 Ospina Vásquez, op. cit., p. 191, opina que esta clase de técnicas estuvo ausente en las operaciones agrícolas normales. Tal punto de vista es quizá correcto para la etapa posterior a la limpieza, pero no para el período inicial. Ver Henao Mejía, op. cit., passim, y von Schenck, op. cit.

52 Gabriel Henao Mejía, op cit., passim, y Parsons, op. cit., capítulos V y VI.

53 Ver Latorre Mendoza, op. cit., pp. 143-145 y 156-157.

54 Henao Mejía, op. cit., y Parsons, op. cit., pp. 75-78. 
tenientes reaccionarios. Lo que sugiere la historia es que el clima general de confusión ideológica, de guerras civiles, de desorden administrativo y de políticas económicas incompatibles que prevaleció durante más de medio siglo después de la independencia, impidió en una $\mathrm{u}$ otra forma la manipulación de los instrumentos del poder central de la nación en favor de los latifundistas. El hecho adicional de que en la Colombia del siglo XIx los intereses de éstos hayan exhibido una variación considerable según las circunstancias económicas y sociales de cada momento o lugar, contribuye a explicar en primer lugar la ausencia de una clase aristocrática monolítica con pleno control del orden institucional, y en segundo lugar la diversidad de desarrollos regionales en las formas de tenencia de la tierra, siendo el caso antioqueño un ejemplo de innovación, democratización y consolidación de una clase media rural.55

La segunda categoría de territorios colonizados en Antioquia durante el siglo xIx, en particular durante los dos o tres primeros decenios de la República, estaba controlada por el grupo capitalista y especulador antes mencionado, como consecuencia del famoso proceso de emisión, negociación y concentración de los bonos agrarios de la administración Santander. ${ }^{56}$ Dado el hecho de que estos bonos fueron emitidos a favor de modestos servidores públicos que se encontraban en precaria situación financiera, su mercadeo ocasionó una castastrófica depreciación, a veces hasta del 90 o $95 \%$, al ser acaparados por un minúsculo sector que disponía de fondos líquidos. Aunque es cierto que este proceso representó una redistribución brutal de los ahorros privados de la comunidad, resulta difícil estar de acuerdo con la opinión de que el instrumento de los bonos frustró por sí mismo un genuino movimiento de reforma agraria democrática. Si se acepta que los acreedores originales del Estado se encontraban en serios aprietos para satisfacer sus necesidades de consumo y saldar sus propias obligaciones; si, por lo tanto, era presumible esperar que el pago directo de tierra a esas personas habría desencadenado una especulación también directa sobre la propiedad raíz por parte de las mismas minorías financistas; y si de otro lado se tiene en cuenta que muchos de los servidores del Estado no eran cultivadores de profesión y carecían de los medios de abrir y explotar nuevas tierras, no parece claro con qué medios, aparte de una expropiación y redistribución de los fondos líquidos privados, se habría podido lograr una democratización efectiva de la propiedad rústica y una amplia reforma de las actividades agropecuarias.

Dentro de los objetivos de este estudio, lo que resulta interesante es la conducta peculiar de los especuladores antioqueños en bonos, quienes, en contraste con sus colegas del resto del país, movilizaron sus recursos con una mentalidad ávida de lucros financieros tangibles y de pronta recuperación del propio capital. Esta motivación capitalista, en armonía con el espíritu comerciante vernáculo de Antioquia,

55 Orlando Fals Borda, La subversión en Colombia. Bogotá, Tercer Mundo, 1967, pp. 127-131.

56 Para una explicación del fenómeno, consúltese Indalecio Liévano Aguirre, Las grandes conflictos sociales y económicos de nuestra historia. Bogotá, Editorial Nueva Prensa, Cap. 38. 
predominó sobre otras consideraciones de prestigio social, influencia política y simple acumulación de propiedad raíz. En vista de las condiciones tan favorables para la adquisición de la tierra, no resulta ningún misterio que para promover las colonizaciones privadas de Antioquia se hayan hecho ofertas muy ventajosas de tierra a los agricultores pioneros y que utilizando las propias palancas del poder local, se haya activado una legislación propicia para la creación de nuevos distritos administrativos, para la asignación de fondos públicos a la construcción de obras de infraestructura física que requería la colonización, y para el desarrollo agropecuario en general.57, 58, 59,60 También es claro que al terminar la primera mitad del siglo, el sistema social y político vigente en Antioquia había evolucionado hacia una etapa en que el latifundio, de por sí, no era ya el símbolo tradicional de riqueza y de poder. El excedente económico del ingreso total generado dentro de la comunidad no fluía tanto hacia una clase de rentistas como hacia una minoría de comerciantes que lo reinvertían en empresas de tipo capitalista, una de las cuales era la compra y parcelación de tierras. ${ }^{61}$

La tercera línea de colonización se orientó hacia los terrenos baldíos, cedidos gradual y libremente por las autoridades. Las características institucionales más interesantes en ese sentido, y que también se hicieron patentes en algunos arreglos privados entre propietarios e invasores en la primera modalidad, consistieron en una serie de medidas que pretendían organizar el poblamiento de un número relativamente grande de centros, en condiciones razonables de ordenamiento social y de control por parte de la administración central antioqueña. ${ }^{2}$ En ausencia del latifundista fuerte que impusiera la cohesión del grupo, se ensayaron instrumentos sustitutivos de la organización comunitaria con marcado acento colectivista en cuanto a la distribución de la tierra y a la administración local. ${ }^{63}$

El primero de estos mecanismos radicaba en el premio social otorgado a la fundación de un nuevo pueblo, lo cual, como ha sido enfatizado en los escritos sobre la colonización antioqueña, representaba el símbolo del éxito en cada nueva aventura migratoria. El nombramiento de junta repartidora, de alcalde y de otros funcionarios locales entre los fundadores, la llegada del cura párroco, etc., facilitaban la articulación de la nueva comunidad a las instituciones existentes y la conectaban algo más directamente al sistema administrativo de lo que ocurría generalmente en los poblamientos latifundiarios, en los que las autoridades locales eran un apéndice nominal al poder del

57 Parsons, op. cit., pp. 88-89, 104105.

58 Entre 1820 y 1850 la mayor parte de los caminos de herradura que se construyeron con recursos particulares en Colombia fueron los de la región de Antioquia. Safford, op. cit., p. 55.

59 Alvaro Restrepo Euse, Historia de Antioquia. Medellín, H. D. B., 1903, p. 228.

60 Havens, op. cit., pp. 42, 47-49.

61 Ospina Vásquez, op. cit., pp. 192-194.

62 Ibid., p. 241.

63 Sin embargo, estos ensayos no podrían con justicia calificarse de socialistas. La propiedad agraria permanecía en cabeza del individuo y no de la comunidad, como fue el caso del ejido mexicano. Véase Whetten, op. cit., p. 9. También, del mismo autor, The Rote of the Ejido in Mexican Land Reform. Land Tenure Center, The University of Wisconsin, Discussion paper 3, mayo de 1963. 
gran hacendado. Un segundo mecanismo lo constituía el tratamiento preferencial otorgado a la primera ola de colonos establecidos en un centro, y que incluía la cesión gratuita de lotes de extensión limitada pero proporcional al número de miembros de la familia. Un tercer mecanismo era la limitación legal de negociar los lotes cedidos antes de que transcurrieran cuatro años, junto con algunos impedimentos a la acumulación individual de tierras más allá de ciertos límites. ${ }^{64}$ Estos arreglos institucionales, que perduraron hasta 1880, reflejaban modalidades de organización comunitaria propias del movimiento colonizador. Tareas como la búsqueda de tierras adecuadas para el asentamiento, la preparación y financiación de una expedición, la quema y tala de bosques, etc., se acometían a menudo por grupos de familias con recursos modestos, que aunaban medios y distribuían riesgos para dar valor económico a tierras sin ninguna función social previa. Si las autoridades de Medellín hubiesen ignorado los esfuerzos colectivos y las expectativas de aquellos pioneros y hubiesen auspiciado la consolidación del latifundio en las nuevas colonias, es presumible que la vigencia de la ley, la preservación del orden público y el control de los conflictos sociales se hubieran convertido en problemas insolubles para una administración pública tan inestable como la de Colombia durante el siglo pasado.

Situación muy diferente fue la de otros movimientos típicos de colonización en América Latina. Por ejemplo, la famosa marcha de los bandeirantes paulistas del Brasil fue organizada, controlada y ejecutada por un grupo de señores que llevaron consigo esclavos y ganado en pos de nuevas tierras y de esclavos indios. Cada empresario establecía su núcleo independiente de poblamiento, dentro del cual se demarcaba brutalmente la separación entre el amo poderoso y los siervos desposeídos. La integración de estos nuevos núcleos al sistema político central dependía entonces de obtener la fidelidad individual del jefe local, a cambio de cederle generosos títulos territoriales o sesimarias, que constituyeron la espina dorsal de la política agraria de las autoridades portuguesas. Este tipo de migración perpetuó y cimentó el andamiaje social de la colonia.65 En el caso antioqueño el movimiento expansionista de la frontera surgió como un escape de fuerzas sociales que no lograban ser contenidas por más tiempo dentro del orden tradicional y que reclamaban formas de organización compatibles con una distribución más equitativa de esfuerzo y de beneficios.

En los tres esquemas de tenencia de las tierras colonizadas se advierte un denominador común. Se trata de la coalición de intereses de colonos pioneros y políticos comerciantes. En muy buena medida la viabilidad del movimiento agrario antioqueño estuvo cuando menos facilitada por tal coalición que, si de un lado no fue necesaria para ponerlo en marcha, sí resultó muy efectiva para canalizarlo y forti-

64 Parsons, op. cit., capítulos 5 y 6.

65 Lymn T. Smith, Brazil: People and Institutions. Baton Rouge, Louisiana University Press, 1963, pp. 320-321. También Celso Furtado, "Amérique Latine: developpement et stagnation", loc. cit. Ver además, del mismo autor, Dialéctica del desarrollo, México, Fondo de Cultura Económica, 1964, capítulo 9. 
ficarlo. Los colonos aportaron a la empresa su espíritu de independencia, su trabajo y su solidaridad a las nuevas instituciones. La burguesía suministró algunos recursos financieros y respaldó el movimiento con su decisiva influencia desde el gobierno. Ahora bien, el grupo gobernante podía encontrar en la fundación de poblaciones y en la apertura de caminos un puntal básico de apoyo a la nueva orientación agraria, dados los beneficios sociales que de allí se derivaban, tanto en el orden político como en el económico. Pero obviamente ese tipo de empresa demandaba un mínimo de esfuerzo y de participación comunitaria que requería una organización colectivista, cuya vigencia se reforzó durante largo tiempo, ya que hacia ella convergían tanto los intereses de colonos como los de la burguesía urbana. Para los primeros, la organización comunal era necesaria con el fin de acometer una empresa difícil y arriesgada. Para los segundos, esa misma organización era un prerrequisito de la clase de obras a través de las cuales se obtenían ganancias económicas y estabilidad administrativa.

Naturalmente, la đistribución de los beneficios a los colonos pioneros asumía en tales circunstancias las características de un bien colectivo, es decir, de un bien que era accesible a cada miembro del grupo, independientemente de su esfuerzo individual previo y de su aporte personal a la obra colonizadora inicial. ${ }^{66}$ Esta circunstancia tendía por su naturaleza a limitar el número de participantes asociados voluntariamente en cada caso específico, fenómeno que en nuestra opinión tuvo un considerable efecto sobre la estructura de la tenencia de tierras derivada de la colonización y sobre las condiciones de cambio social en Antioquia, y que por lo tanto merece ser analizado. Quizá fue el filósofo inglés David Hume uno de los primeros pensadores en destacar los motivos psicológicos que permiten lograr a un grupo reducido propósitos comunes que no pueden emprender colectividades numerosas: Two neighbours may agree to drain a meadow, which they possess in common; because it is easy for them to know each other's mind; and each of them must perceive that the immediate consequence of his failing in his part, is the abandoning of the whole project. But it is very difficult, and indeed impossible that a thousand persons should agree in such an action; it being difficult to concert so complicated a design, and stitl more difficult for them to execute it, while each seeks a pretext to free himself of the trouble and expense, and would lay the whole burden on others. ${ }^{67}$ En reciente estudio, el economista norteamericano Mancur Olson ha hecho un análisis penetrante sobre las condiciones de acción de grupos dirigido a la obtención de un bien colectivo, en el cual se aportan razones adicionales para esperar una menor eficacia en empresas de este género, cuando son acometidas por un número grande de personas. La idea central de Olson consiste en que en un grupo poco numeroso que está creando o produciendo un bien colectivo, la proporción del beneficio total que

66 Una discusión de la naturaleza colectiva de la fundación de poblaciones caldenses en el siglo XIX se encuentra en Antonio García, Geografía económica de Colombia, Caldas. Bogctá, Contraloría General de la República, 1937, pp. 30-36.

67 David Hume, A Treatise of Human Nature. Londres, Everyman's Edition, J. M. Dent, 1952, vol. II, p. 239. 
corresponde a cada miembro es relativamente alta; siendo posible que el beneficio absoluto para algunas de las personas sea mayor que el costo total, aunque ellas sobrelleven una cuantía desproporcionada del mismo. De ello infiere Olson dos consecuencias: la primera, que en los grupos reducidos dentro de los cuales existe desigualdad de intereses por parte de sus integrantes en la adquisición del bien colectivo, las probabilidades de éxito son mayores, en igualdad de otras condiciones; la segunda, que mientras más se amplíe el grupo, más se apartarán sus resultados de la adquisición óptima del mismo bien. ${ }^{68}$

Varios ejemplos sugieren que en el periodo de los años 1800 a 1880 , durante los cuales predominó en Antioquia la organización comunitaria de la colonización, la política de concesiones agrarias tendía a favorecer a un número reducido de familias. Utilizando los datos de la obra clásica de Parsons, se observa que la concesión típica de tierras baldías para nuevas poblaciones era del orden de 15000 fanegadas, distribuyéndose las parcelas en extensiones que fluctuaban entre 60 y 150 fanegadas. ${ }^{69}$ Es decir, que apenas unas 150 a 200 familias recibían tierras en cada caso. Sonsón, Abejorral, Pácora y Salamina fueron fundadas por un número reducido de familias; Manizales, por la célebre expedición de los veinte. Cuando en 1874 se expidió la ley nacional que concedía apoyo pleno a la colonización individual, las reglas del juego habían cambiado sustancialmente. Tocaba a su término el período de orientación federalista; las posiciones de alto mando político en Antioquia no estaban ya en manos de la élite comerciante y ésta orientaba sus actividades financieras hacia ramos distintos de la colonización; la extensa red de poblaciones en el suroeste y el sur del estado de Antioquia comenzaba a saturarse y la introducción del pasto pará estimulaba el establecimiento de haciendas de engorde de ganado con uso extensivo de la tierra, en condiciones ventajosas para sus propietarios aunque con pocas posibilidades de absorción de recursos humanos. Para éstos, el tránsito de la colonización colectiva a la individual representaría un mejoramiento positivo de oportunidades, en especial al iniciarse en escala considerable la explotación cafetera. En este segundo período de colonización se intensificaría sustancialmente la migración, se superarían las condiciones de economía cerrada que predominaba antes en los pueblos y se democratizaría más la tenencia de la tierra, ${ }^{70}$ no obstante las aberraciones latifundistas que se presentaron en algunos sitios en donde la guaquería distrajo la atención de los pioneros y dio lugar a la especulación agraria de unos pocos. ${ }^{71}$

\section{b) Dinámica económica de la colonización}

Las presiones sobre la emigración que se manifestaron en Antioquia durante el primer período colonizador actuaron con particular intensidad en aquellos centros de poblamiento colonial en donde las condiciones físicas inferiores para el cultivo de la tierra se combi-

68 Mancur Olson, Jr., The Logic of Collective Action, Public Goods and the Theory of Groups. Cambridge, Harvard University Press, 1965, pp. 22-36 y 34-35.

69 Parsons, op. cit., pp. 102-103.

70 Alejandro López, op. cit., pp. 47-55.

71 Antonio García, op. cit., pp. 33, 237-238. 
naban con una notoria concentración de la propiedad y en donde el uso de los recursos empresariales se orientaba hacia actividades no agrícolas, que, como era el caso del comercio, ofrecían una capacidad muy reducida de absorción de brazos. Para los grupos que ejercían una modesta actividad autónoma, como los mineros, la progresiva y aguda escasez de alimentos y la dependencia extrema que tal escasez les determinaba con respecto al rescatante, esas mismas presiones contribuyeron a una mejor percepción de acometer los riesgos de una expedición invasora a tierras abandonadas y de título ambiguo y a orientar su labor hacia una producción más equilibrada de víveres y de oro.

Una característica sobresaliente de las tierras así pobladas fue su fertilidad superior con respecto a las tradicionales, lo cual indujo una reversión del anterior proceso de extensión de la frontera a la Ricardo, que como se ha visto incorporaba con el correr del tiempo suelos de inferiores condiciones, generando presumiblemente una renta sobre las propiedades agrarias inframarginales. Aunque no existen fuentes disponibles para identificar las consecuencias que el nuevo estado de cosas representó para los beneficiarios de renta diferencial, se sabe que poco tiempo después de iniciada la implementación de las reformas de Mon y Velarde se percibió una rebaja en los precios del maíz en algunos distritos mineros y una contribución de abastecimientos provenientes de las nuevas colonias en épocas de mala cosecha. ${ }^{72}$

Para fines de un análisis económico del proceso de colonización conviene tener muy claro el hecho de que, no obstante que la extensión de la nueva frontera fue más una empresa de hombres de recursos modestos que un negocio de grandes terratenientes, existían tres factores que frustraban la posibilidad de ampliar la extensión de los cultivos hasta el punto de anular el producto marginal de la tierra, o siquiera hasta el punto de eliminación de ingresos por concepto de renta agraria. En otros términos, no se trata del modelo clásico de colonos libres (freeholders) en el que la proporción de los dos factores básicos de la producción, hombre y tierra, se adapta idealmente en toda la periferia fronteriza para lograr un índice óptimo de densidad demográfica que garantiza rendimientos máximos para la mano de obra. ${ }^{73}$ En primer lugar, ya hemos visto que la índole colectiva de muchas de las primeras colonizaciones tendía a reducir el número de participantes dentro de una misma expedición. Además, el número de expediciones quedaba restringido por cuanto no eran muchos quienes, en medio de un clima económico general desfavorable, disponían de recursos para sobrellevar el período inicial de la expedición, que requería disponer de mulas, herramientas, comestibles para los trabajadores y sus dependientes, etc. En esta forma el movimiento sólo lograba atraer hacia sus etapas iniciales una proporción reducida del número

72 Parsons, op. cit., pp. 70-74.

73 Ese modelo teórico describe el caso más simple de una economía de frontera, operada por un número dado de colonos con eficiencia igual y homogéneos desde el punto de vista de su movilidad y su acceso a los recursos. Constituye este esquema una intersección de los que la economista Joan Robinson llama modelo de colonos (freeholders) y modelo de hombres de frontera (frontier men). The Accumulation of Capital. Londres, Macmillan \& Co., 1958, pp. 287-288 y 297. 
total de personas para quienes las labores agrícolas o mineras de la frontera podían reportar niveles superiores de ingreso. Es decir, aquellos emigrantes de mayores recursos o provistos de un espíritu más aventurero lograban fundar una nueva colonia, reservarse las mejores tierras y obtener los demás privilegios legislativos para los primeros en llegar. ${ }^{74}$ Después de ellos se presentaba una segunda ola migratoria, cuyos integrantes encontraban el camino preparado, requerían poco esfuerzo y recursos para desplazarse a una colonia próspera, pero en muchos casos ya no encontraban tierras disponibles para la distribución y tenían que ofrecer sus servicios a los pioneros en condición de dependientes.

Algunas pruebas históricas pueden ser aducidas para indicar que efectivamente en la colonización antioqueña se manifestaron fenómenos de considerable estratificación social, aunque en ningún caso comparables a los de la estructura tradicional de poblamiento rural en América Latina. Por ejemplo, Parsons encontró en un documento censal de comienzo del siglo xıx que en la colonia de Abejorral el número de familias agregadas era el triple de aquellas "dueñas de posesión".75 En épocas posteriores las autoridades de Medellín desplazaron hacia la frontera un número considerable de mendigos, vagos y criminales que ayudasen en obras de construcción y de preparación de tierras. ${ }^{76}$ Ejemplos como éstos sugieren que el colono pionero lograba extraer de su tierra una cierta cantidad de renta y que su deseo de incrementar los ingresos de la parcela por concepto de su trabajo y del excedente extraído de los frutos de sus dependientes, no era del todo compatible con una situación de máxima retribución al factor mano de obra en condiciones de oferta ilimitada de tierra.

El segundo factor que afectaba la proporción entre área cultivada y población rural se derivaba de un tipo de asentamiento en el cual, en torno a los núcleos de colonización donde se distribuía la tierra de acuerdo con normas colectivistas, subsistían vastos espacios en poder de los terratenientes, cuya explotación renovaría las relaciones sociales entre peón y patrono en detrimento de la posición de labriego independiente, dando lugar así a lo que el escritor antioqueño Alejandro López llamó "una lucha sorda entre el papel sellado y el hacha".77 La conversión de estos espacios en haciendas tuvo que esperar hasta cuando se hicieron presentes factores favorables como el aumento de la población, la acumulación de capitales, la sustitución de una economía de subsistencia por una economía monetaria, la construcción de vías de comunicación más eficientes que los viejos caminos de herradura, etc. No siendo ya libre el acceso a la tierra para un número considerable de agricultores, la combinación de producción dependía de los intereses del hacendado por maximizar su cuota de cuasi-renta. En algunos sitios se establecieron dehesas de ganado con capacidad total hasta de 60000 o más cabezas y con empleo reducido de vaque-

74 La importancia de esta clase de recursos en la mayoría de los movimientos colonizadores ha sido subrayada por W. A. Lewis, "Thoughts on Land Settlement", Journal of Agricultural Economics, vol. II, pp. 3-11.

75 Parsons, op. cit., p. 206, nota 11.

76 Alvaro Restrepo Euse, op. cit., p. 172.

77 Alejandro López, op. cit., pp. 46, 55-63. 
ros. En otros lugares, las plantaciones de caña de azúcar y de café implicarían, dentro de una proporción hombre-tierra mayor que en el caso anterior, condiciones de tenencia bien distantes del modelo del pegujal y favorables en todo caso a la explotación de los peones.78, 79

El tercer factor que conspiraba en contra de la obtención de buenos rendimientos para el labriego y de la optimización en el uso de sus recursos era el de la vigencia de economías embotelladas en los centros colonizadores, hasta el advenimiento de la industria cafetera. Parsons señala algunas excepciones a este fenómeno, como los despachos de maíz desde Sonsón a Medellín, y los mercados de cerdos criados en Manizales y El Quindío. ${ }^{50}$ En cambio, la característica de economías cerradas que se desarrolló en torno a la mayoría de las poblaciones fundadas en Antioquia y Caldas durante el siglo XIX ha sido un fenómeno muy destacado por escritores colombianos como Alejandro López ${ }^{81}$ y Antonio García. ${ }^{82}$ Este último en particular ha explicado cómo en el seno de esos grupos de escaso poder de compra surgían instituciones como las fondas, verdaderos ejes de un mercado de monopsonio, especulación y usura. López delataba aún la prolongación de este estado de cosas hasta comienzos del siglo $\mathrm{xx}$ con respecto a las compras de algodón costeño y vallecaucano por parte de las pocas empresas textiles de Medellín.

En síntesis, resultaría superficial y errado describir el desarrollo de la frontera colonizadora de Antioquia y Caldas como una réplica en menor escala del movimiento de la población norteamericana hacia el oeste. Diversas causas contribuyeron a que la agricultura no se explotara en nuestro medio siguiendo las líneas de uso intensivo de la tierra, de elevada productividad del trabajo y de máximo aprovechamiento de esa productividad por parte del cultivador en general. ${ }^{83}$ Entre esas causas, las más importantes fueron: 1) la índole de las normas institucionales que regulaban el acceso a la tierra; 2) la ausencia de una economía urbana dinámica, o de frentes estables y voluminosos de obras públicas, que compitiesen por la oferta disponible de brazos y generasen suficientes ahorros para mejorar las oportunidades de adquisición de tierras a un gran número de trabajadores; 3 ) el demorado desarrollo de una amplia economía monetaria, que frenó aún más las posibilidades de ahorro por parte del agricultor; 4) la ausencia de un factor que jugó un papel fundamental en la colonización estadounidense, y que era la disponibilidad de vías navegables (naturales o

is Hacia 1910 había en la región antioqueña de la hoya del Cauca, unas cien haciendas con una capacidad de engorde variable de entre 200 y 2400 cabezas, en tanto que existían dentro del departamento, excluyendo a Caldas y las zonas de colonización del Tolima, unos 30 millones de árboles de café, cuyos propietarios se quejaban de falta de brazos, aunque forzaban la existencia de una gran población flotante. Ibid., pp. 246-249. También Alejandro López y Jorge Rodrí-

guez L., Estadística de Antioquia. Medellín, Gaceta Antioqueña, 1914, pp. 133-136.

79 Ospina Vásquez, op. cit., p. 284, nota 27.

so Parsons, op. cit., pp. 74, 83, 207, nota 23.

81 Alejandro López, Problemas colombianos, pp. 51, 128-129.

82 Antonio García, op. cit., p. 34.

s3 Un original análisis económico de la frontera rural de los Estados Unidos durante el siglo XIX se encuentra en la obra de Habakkuk, H. J., American and British Technology in the Nineteenth Century. Cambridge, University Press, 1962, pp. 11-17, 22-24, 34-43. 
artificialmente construidas por las autoridades) o de medios alternativos de transporte que permitiesen mejores condiciones y reforzaran la participación del labrador ordinario en las ganancias de capital que generaba el proceso de expansión de la frontera. ${ }^{84}$

De otro lado, no se debe ignorar el hecho de que, no obstante las limitaciones de orden institucional y económico que pesaron sobre el nuevo tipo de asentamiento de la población antioqueña, los rendimientos derivados por el cultivador mejoraron considerablemente como consecuencia de la colonización, en abierto contraste con lo que ocurrió después de la independencia en otros lugares de Colombia. Hacia 1880, varios observadores atribuían un nivel de vida más alto al campesino antioqueño que al del resto de las zonas rurales del país, ${ }^{85}$ situación diametralmente opuesta a la de un siglo atrás. Además, en la medida en que el excedente de producción del campesino fue captado por hacendados y comerciantes de mentalidad capitalista, se propiciaba un proceso de acumulación benéfico para el conjunto de la economía regional..$^{86}$

Hasta ahora los objetivos de nuestra discusión han sido dirigidos a enfocar algunos hilos claves de la compleja trama de factores que incidieron en las condiciones de asignación de factores productivos dentro de la economía de colonización y sobre la distribución de los ingresos de esos mismos factores. En íntima relación con estos mecanismos reguladores operaba el proceso mismo de desplazamiento de la frontera, tanto en lo que respecta a su escalonamiento en el tiempo como a su orientación geográfica y económica, fenómenos sobre los cuales convergía una pluralidad de fuerzas económicas y no económicas. Con respecto a las últimas, lo más importante es quizás destacar la influencia del clima político que caracterizó la vida colombiana durante el siglo XIX. La guerra de independencia, la larga lista de guerras civiles y de alzamientos de menor importancia, las persecuciones políticas a que se veían sometidos los enemigos del partido que detentaba el poder, etc., eran todos factores que actuaban en forma conflictiva sobre la intensidad de los movimientos migratorios, sin que su resultante neta fuese la misma en todo tiempo y lugar.

Es cierto que los reclutamientos, los temores al desorden y a la inseguridad en los campos, la interrupción de las líneas normales del comercio, la parálisis en las inversiones, etc., produjeron retardos y otros efectos desalentadores sobre el movimiento colonizador en ciertos períodos. ${ }^{87}$ Pero también es verdad que el temor a la confiscación de bienes, a la represalia política y a la participación en las luchas fueron en ocasiones fuente de estímulo para iniciar vida nueva en lugares distantes de los principales centros urbanos. No obstante, hay que tener en cuenta que la ausencia relativa de actividades políticas en los frentes de colonización no significaba necesariamente una exis-

84 Ibid.

85 Von Schenck, op. cit., pp. 20, 35, 36 ss. También Miguel Samper, Escritos políticos-económicos, vol. 2. Bogotá, Editorial Cromos, 1925, pp. 419-424. Ospina Vásquez, op. cit., pp. 427-430.

86. Ospina Vásquez, op. cit., pp. 446-447.

87. Así, por ejemplo, Antonio García habla de un período de aparente quietismo en la colonización del noroeste de Caldas entre 1820 y 1840, en parte como consecuencia del estado caótico nacional; op. cit., p. 36 . 
tencia pacífica y segura, sobre todo si estaba de por medio un conflicto entre propietarios y colonos. No fueron pocas las veces que estos conflictos dieron lugar a intervenciones a mano armada y a complicados litigios, que hacían muy azarosas las condiciones de vida familiar, de tenencia y de usufructo de las mejoras hechas a la tierra. En algunos de estos casos, el flujo migratorio tendía a contraerse o a desviarse hacia otros territorios en los que el asentamiento de la población podía avanzar en condiciones más favorables.

Sin desconocer la importancia de otros factores no económicos que contribuyeron a moldear el movimiento agrario antioqueño del siglo pasado, tales como el ánimo de vida independiente que había forjado la brega minera, los intereses políticos de la clase gobernante, etc., deseamos prestar especial atención al análisis de los factores económicos que gravitaron sobre la movilidad y sobre la asignación de los factores de producción operantes en la economía de colonización. Entre estos factores, la búsqueda del oro desempeñó un papel fundamental como punta de lanza de las migraciones y como determinante de la localización de muchos poblamientos. Pero en muchos casos la atracción no provino de la existencia de yacimientos sino de la búsqueda de sepulturas y tesoros indígenas. El caso de la ocupación de las tierras del Quindío es un buen ejemplo en este sentido.

En general puede decirse que las actividades mineras no reportaron una fuente permanente y significativa de ingresos para la mayoría de los colonos. Las mismas condiciones geológicas que determinaban mayor fertilidad de los suelos volcánicos del sur de Antioquia eran responsables de una dotación natural más pobre de metales preciosos fácilmente accesibles. Esta diferencia en la constelación de los recursos se conjugó con las favorables innovaciones institucionales para afirmar un viraje esencial en la historia económica de la población antioqueña, después del cual se corrigió el desequilibrio secular entre minería y agricultura que había conducido a la crisis de fines de la Colonia. A pesar de las limitaciones de una economía de semisubsistencia, pudo así aliviarse la escasez crónica de alimentos que antes estrangulaban no sólo el proceso de desarrollo económico, sino también el demográfico.

Enlazado a estos cambios en la dotación de recursos naturales, actuaba un fenómeno de disponibilidad de capital físico y de tecnología que, dentro de las limitaciones impuestas por la demanda, contribuia a determinar las modalidades de la combinación de factores productivos en los territorios de frontera. La escasez de capital de los centros tradicionales de poblamiento contrastaba con una relativa abundancia de tierra en las áreas de colonización. La intensidad de este contraste no era uniforme, como tampoco lo fue la fuerza del mecanismo de expulsión y atracción que activó el flujo migratorio desde lugares en donde las escasas oportunidades de ocupación estaban acompañadas por el predominio de actividades con uso intensivo de capital como el comercio y la minería capitalista, hacia lugares en donde el trabajo humano podía combinarse con dosis abundantes en tierras e insignificantes en capital. En épocas en que la tasa de interés de los rudimentarios mercados financieros marcaba niveles excesivamente altos, la emigración tendía a la vez a intensificarse y 
a orientarse hacia los territorios baldíos, en donde la relación hombretierra podía ampliarse al máximo. 88

Pero más allá de estas fluctuaciones anómalas en la relación de disponibilidad y costo de los factores de la producción, el movimiento de colonización se resintió en todo momento de una extrema pobreza de capital físico, en particular en las facilidades de infraestructura como transporte, fuentes de energía, medios de almacenamiento, calidad de las construcciones, etc. Inclusive el uso del alambre de púas para los cercos apenas comenzó a generalizarse hacia 1870.89 Estas circunstancias, agregadas a otros hechos análogos explicables como las prácticas de desgaste del suelo, la ausencia de medios de mecanización de algunas labores, la lentitud en la introducción de variedades de semillas, etc., deben tenerse muy en cuenta para evitar comparaciones equivocas con las condiciones de la agricultura de los Estados Unidos durante el mismo período. ${ }^{90}$

Por otra parte, hay que reconocer que el uso de métodos de tala y quema de los bosques en las labores de preparación de tierras, si bien es cierto implica un desgaste de los suelos, conlleva niveles de productividad más altos por unidad de trabajo humano, e implicaría en cierta forma un uso racional de los recursos en regiones de baja densidad demográfica y reducido nivel de ingresos por habitante.91 Asimismo, y como varios autores han destacado, ${ }^{92}$ esta técnica de cultivo no trajo consigo una modalidad de "frontera hueca", en la que las tierras detrás de las líneas de avanzada entrasen en desuso total después de que al cabo de unas pocas cosechas quedase exhausta la fertilidad de los suelos. A menudo esas tierras se convirtieron en prósperas haciendas de ganado que aunque absorbían poca y mal pagada mano de obra, desempeñaron un papel de gran importancia en el desarrollo de la industria pecuaria vernácula y en el proceso de acumulación de capital. Entre la época de la Independencia y 1880 las existencias de ganado vacuno en Antioquia se multiplicaron veinte veces.93 La disponibilidad de ganado vacuno local por habitante de esa época alcánzó niveles mucho más altos que los de épocas recientes y fue el fruto de un genuino proceso de acumulación de riqueza que no estuvo equiparado por ningún otro renglón de la economía antioqueña du. rante el mismo período.

Después de 1880 cobró fuerza el cultivo del café, que restó bases a la economía nómada del maíz, el frijol, el plátano y los cerdos y abrió las puertas a una actividad más sedentaria y articulada al sistema de mercado. Pero más que una reacción a las presiones derivadas de una densidad demográfica superior, que en la literatura contemporánea han sido identificadas como uno de los más dinámicos agentes

88 Parsons comenta las quejas contra los prestamistas y gamonales de Rionegro como factor influyente en la colonización del Quindío; op. cit., p. 208, nota 38 .

89 Ospina Vásquez, op. cit., p. 242.

90 Sobre los incentivos de cambio tecnológico en las granjas de los Estados Unidos durante el siglo XIX, véase Habakkuk, op. cit., pp. 101-102.

91 Una discusión de esta tesis se encuentra en Esther Boserup, The Conditions of Agricultural Growth, Aldine Publishing Co., 1965, pp. 23-27, 28-34, 43-55.

92 Hirschman, op. cit.; Ospina Vásquez, op. cit., pp. 191-192.

93 Von Schenk, op. cit., p. 36. 
en la sustitución de unos métodos de cultivo por otros, ${ }^{94}$ la secuencia en las formas de uso de la tierra que se registró durante distintas etapas de la colonización antioqueña parece explicarse mejor como la respuesta natural a los requisitos de una economía de propietarios ganaderos, por una parte, y de cafeteros orientados hacia los mercados de exportación, por otra. ${ }^{95}$

No obstante lo anterior, pecaría de muy incompleto cualquier análisis de la colonización que no incorporase la influencia recíproca que entre sí ejercieron la aceleración del crecimiento demográfico y las nuevas labores agrícolas. Hasta 1778, momento en que se levantó el primer censo del siglo XvIrx en la provincia, la población de Antioquia no llegaba según datos oficiales sino a 46500 habitantes, mientras según los estimados de Parsons, hacia 1675, fecha de la instalación formal de Medellín, la población de la provincia apenas excedía de 25000 personas. Si hacemos fe a esta cifra, a lo menos como un límite mínimo de la cifra real, tendríamos que durante la mayor parte del período colonial la población apenas lograba duplicarse en un período de poco más de cien años. La cifra de población total correspondiente al segundo censo del siglo xviII, que fue de 1787, alcanzó a 56000 habitantes, ritmo al cual el período de duplicación se reducía a unos 34 años. En el censo de 1808 la población alcanzó a 110000 habitantes, o sea que la población prácticamente se duplicó en 23 años. Igual cosa ocurrió entre los censos de 1828 (120000 habitantes) y 1851 (244 000). La tasa de crecimiento entre los censos de 1843 (189000 habitantes, ritmo al cual el periodo de duplicación se reducía a unos 27 años. ${ }^{96}$

Lo anterior sugiere a grandes rasgos que la línea de crecimiento demográfico puede dividirse en dos períodos, o sea antes y después de 1780-1790, o lo que es lo mismo, antes y después de abrirse los frentes de colonización. Aun descontando la posibilidad de errores significativos en las cifras censales, la consistencia interna de los datos no permitiría en ningún caso una tasa mayor del $1.0 \%$ anual en el primer período, en tanto que las tres comparaciones del segundo período arrojan una tasa que oscila entre 2.5 y $3.0 \%$ anual. El contraste es demasiado brusco y el período de cambio de régimen demasiado conspicuo para poder atribuirse el fenómeno a simples accidentes de metodología censal. Resulta pues muy tentador enmarcar nítidamente el caso demográfico antioqueño dentro del clásico modelo malthusiano: hasta fines de la Colonia, la escasez de alimentos y las precarias condiciones de subsistencia de los grupos mineros estrangulaban el crecimiento demográfico por medio de frenos positivos, entre los cuales posiblemente figuraban una intensa mortalidad y una moderada nupcialidad. Posteriormente, la solución del problema de abastecimientos y el traslado gradual de la población a climas más benéficos

94 Boserup, op. cit. También Colin Clark, Population Growth and Land Use. Nueva York, Macmillan, 1967, en particular el capítulo IV.

$95 \mathrm{La}$ importancia excepcional de ambos fenómenos para la comprensión de la historia económica de Antioquia fue subrayada por Alejandro López, op. cit., pp. $48-50$.

96 Todos estos datos se toman de la obra de Parsons, op. cit., pp. 65 y 109. Básicamente, éstas. 
habrian amortiguado sustancialmente el primer freno, en tanto que la consolidación de los hábitos campesinos, el tránsito del minero al labriego, la repartición de tierras en proporción al número de miembros de la familia, etc., podrían haber intensificado la frecuencia de los matrimonios y la fuerza de la fecundidad marital.

Dadas las condiciones de estratificación social en las colonias es natural que el incremento de la densidad demográfica dentro de una de ellas, tanto por migración como por aumento vegetativo, indujese una elevación de la renta de la tierra, ofreciere oportunidades de realizar ganancias de capital en operaciones de propiedad raíz y generase incentivos para extender la frontera. En la medida en que la emigración hacia tierras de nuevas colonias revertía el proceso de incremento de la renta en las ya establecidas, lesionándose con ello los intereses de sus terratenientes, no resulta difícil comprender la oposición de éstos a la fundación de nuevos pueblos. Tal fue el caso de los sonsoneños con respecto a Salamina. El permiso de la fundación de Pensilvania también fue rehusado durante algún tiempo por las autoridades del Tolima. ${ }^{97}$ Estos ejemplos podrían interpretarse como evidencias adicionales de la importancia que tuvo el factor de renta de la tierra en los beneficios de los colonizadores antioqueños. En tanto que en la frontera de los Estados Unidos el mejoramiento de los réditos del granjero dependía básicamente de factores como la baja de los costos del transporte, la búsqueda de métodos de mecanización que permitiesen elevar la cantidad de tierra por trabajador y el desarrollo de nuevas variedades agrícolas y pecuarias, la tecnología rural en Antioquia permaneció esencialmente estancada por lo menos hasta el tercer cuarto del siglo XIX. Este estancamiento, sumado al de la demanda, condicionó en buena parte la suerte del pionero colonizador a las posibilidades de extraer renta de sus parcelas.

Al término de esta discusión conviene, aun a riesgo de repetición, resumir los logros y limitaciones del movimiento de colonización antioqueño hasta 1880. Del lado positivo se destacan: primero, la superación del estrangulamiento en la producción agropecuaria que había sumido la economía de la vieja provincia en la más absoluta decadencia; segundo, el alza del nivel de vida y la creación de nuevas oportunidades de trabajo para una capa social muy necesitada; tercero, la acumulación de capital en ganado y en desmonte de fincas; cuarto, el desarrollo de una población más numerosa, menos estratificada socialmente y con mejores condiciones de movilidad ocupacional y territorial. Intimamente ligada a todos estos procesos, hay que mencionar la diversificación de las actividades del poderoso grupo comerciante, directa e indirectamente relacionadas con la colonización. Las empresas especulativas en concesiones, la ampliación de los mercados de artículos de importación, la experiencia política en cuanto al fomento de una nueva orientación agraria, etc., fueron todos factores que contribuyeron a ampliar el horizonte de acción de este influyente grupo y a arraigar en él una tradición empresarial cuyos frutos se multiplicarían al iniciarse posteriormente la gran corriente de industrialización. Del lado negativo es posible anotar las siguientes limitaciones: pri- 
mera, la desigualdad social de los beneficios otorgados a los emigrantes; segunda, la operación del movimiento colonizador dentro de un sistema político sometido a recurrentes convulsiones; tercera, el predominio de una economía de semi-subsistencia a la cual hasta 1880 estaban dedicadas las dos terceras partes de la fuerza de trabajo antioqueña, ${ }^{98}$ lastrada por muy deficientes condiciones de transporte, por una tecnología incipiente y por muy desfavorables mecanismos de mercadeo; cuarta, la destrucción masiva de recursos forestales que, como consecuencia de las prácticas de cultivo, tendría que descontarse de la acumulación de capital en la apertura de parcelas y en el establecimiento de haciendas.

\section{El ascenso de la clase empresarial}

El tránsito de la Colonia a la República modificó sustancialmente el medio económico dentro del cual habrían de moverse los reducidos grupos neogranadinos que explotaban las actividades comerciales. La liberación del monopolio comercial español facilitó el acceso a la adquisición de mercancías inglesas, particularmente en el caso de las manufacturas textiles de algodón, que gradualmente desalojaron la producción local de tipo artesanal.99 Desde el régimen del general Santander las importaciones colombianas sobrepasaron ampliamente los niveles del período colonial ${ }^{100} \mathrm{y}$, al superar por un considerable margen el correspondiente valor de las exportaciones, ${ }^{101}$ ejercieron una fuerte presión sobre la oferta interna de oro y sobre las fuentes externas de financiamiento. Esta presión se reforzaba por la tendencia de la hacienda pública que, operando dentro de un sistema monetario primitivo e inelástico, ejercía por su parte demanda adicional sobre las disponibilidades de fondos internos y externos, toda vez que el fuerte incremento de los gastos públicos que trajo consigo el establecimiento del gobierno republicano no estuvo acompañado de un correspondiente robustecimiento de los ingresos ordinarios del Estado. ${ }^{102}$

Déficit comercial, déficit fiscal y pagos exclusivos en oro eran entonces tres factores que se conjugaban para fortalecer extraordinariamente la posición económica y social de quienes ejercieran la ocupación de comerciante, tuviesen experiencia en operaciones financieras y mantuvieran un control sobre las disponibilidades de oro. A primera vista parecería que este último era al fin de cuentas el elemento decisivo de supremacía económica dentro de las circunstancias descritas y así lo afirmaban observadores de la época..$^{103}$ Pero quizá la realidad era más compleja porque el desarrollo y el control de una oferta de

98 Datos del censo de 1883.

99 Ospina Vásquez, op. cit., pp. 131, 171; Mollien, Viaje por la República de Co lombia en 1823, Bogotá, Biblioteca Popular de Cultura Colombiana, 1944, p. 92.

100 David Bushnell, El régimen de Santander en la Gran Colombia. Bogotá, Coediciones de Tercer Mundo y Universidad Nacional, 1966, p. 189. (Traducción.) 101 Ibid. También Nieto Arteta, op. cit., pp. 331-332, 347, 350, en donde se tienen algunos estimados sobre la exportación de oro amonedado en 1834-1845.

102 Bushnell, op. cit., capítulos vr y vir.

103 Magnus Mörner, "El comercio de Antioquia alrededor de 1830 según un observador sueco", Anuario Colombiano de Historia Social y de la Cultura, Bogotá, 1964, Vol. 1, núm. 2, p. 324. 
oro más abundante y elástica requería una profunda transformación de la industria minera, tanto más cuanto el contexto social y político de las guerras de la Independencia había agudizado el proceso erosivo de la economía esclavista. En otros términos, no podría decirse que los grupos o las regiones que habían sido abastecedoras tradicionales de oro, por el solo control de los recursos naturales, tenían automáticamente asegurada la llave maestra del poder financiero, de la gestión empresarial y de la influencia social. Más exacto sería afirmar que la disponibilidad de recursos empresariales, junto con la propensión a innovar, a asumir riesgos y a asociar esfuerzos, eran requisitos básicos para transformar y hacer más productiva la actividad minera, cuyos frutos permitirían no sólo la colocación de capitales y la percepción de rentas, sino también la aplicación y el desarrollo del espíritu de empresa en nuevas combinaciones de tipo comercial y financiero.

Es en este sentido en el que contrasta más fuertemente la conducta económica de los grupos caucano y antioqueño después de la Independencia. La producción combinada de las minas de Cauca y Chocó había sido en el siglo xviıI de $\$ 90$ millones oro, mientras la de minas de Antioquia sólo había alcanzado a $\$ 64$ millones. La posición absoluta y relativa de ambas regiones cambió radicalmente en el siglo xIx. Mientras Antioquia elevó su producción de oro a $\$ 137$ millones en la centuria, Cauca la redujo a $\$ 80$ millones. ${ }^{104}$ Hubo así una respuesta muy diferente por parte de uno y otro grupo minero ante las oportunidades y el premio económico que llegó a significar el control del oro en el régimen republicano. Parece que la minería caucana fue muy lesionada por el reclutamiento de esclavos durante la guerra de Independencia, por su liberación posterior, por los mayores disturbios sociales y políticos que experimentó la región a lo largo del siglo XIX y por la menor eficiencia en el trabajo de los negros libres. ${ }^{105}$ Así que la industria del oro dejó de ser la extraordinaria fuente de riquezas que había sido para un reducido número de familias payanesas. Pero también Antioquia había sufrido una crisis definitiva de su minería esclavista desde fines de la Colonia y un gran deterioro del poder económico de los concesionarios tradicionales. Más que un contraste de situaciones entre ambas regiones hubo una diferencia de procesos que condujeron a la decadencia de la explotación convencional y una diferencia de reacciones para salir del impasse.

Fue así como desde los primeros años de la República se establecían en Antioquia sociedades de minería, se introducían nuevos sistemas de operación de vetas a base del uso de molinos de pisones, de energía hidroeléctrica y fundición, de aprovechamiento de los minerales argentíferos y de mejor recuperación de los auríferos, al tiempo que se buscaba la cooperación técnica de personal europeo inmigrante. A este respecto fue muy importante la vinculación obtenida a través de la casa Goldschmidt en ocasión del famoso empréstito inglés negociado en 1824 para el gobierno colombiano por comerciantes y financistas antioqueños. ${ }^{106}$ En vista de que el servicio de la deuda debía

104 Estimaciones de Vicente Restrepo, op. cit., pp. 71 y 104.

105 Ibid., passim. Mollien, op. cit., pp. 263-266, 383.

106 Bushnell, op. cit., pp. 138-141. Liévano Aguirre, op. cit., capítulo 40. 
hacerse en oro, la casa prestamista inglesa se interesó en asegurar una asistencia técnica y una explotación más productiva de los yacimientos mineros, para lo cual obtuvo el envío a Colombia de ingenieros alemanes e ingleses. ${ }^{107}$ Fue así como la misma firma tomó al gobierno en arrendamiento varias minas de oro en Supía y Marmato que sus dueños habían abandonado hacía algunos años. ${ }^{108} \mathrm{Al}$ producirse la quiebra financiera de la firma inglesa, los expertos mineros fueron absorbidos por los empresarios de Antioquia (no obstante que aquellas minas estaban localizadas en territorio caucano), obteniéndose así recursos humanos especializados de mucho valor para hacer posible un vuelco de las modalidades de explotación. De acuerdo con la opinión de Vicente Restrepo, estos hechos apenas lograron un fuerte impacto sobre la minería antioqueña a partir de 1850 , cuando las innovaciones tecnológicas se extendieron en un frente suficientemente amplio. 109 Otros observadores comentaban que hacia 1830 las mejoras técnicas introducidas en la minería antioqueña por los europeos habían fortalecido en forma asombrosa las explotaciones y hacían sentir la necesidad de importar máquinas, instrumentos, herramientas y pólvora para un mejor éxito de los nuevos sistemas de producción. . $^{10}$ No parece haber habido un desarrollo comparable de la minería caucana y chocoana hasta fines del siglo XIX. Según varios expertos ingleses, el uso de herramientas elaboradas, de taladros, de bombas, de pólvora, etc., era desconocido hasta 1880 en esas regiones. ${ }^{111}$

Del lado antioqueño, los mismos recursos empresariales que estaban logrando una combinación más eficiente de los factores de la producción existentes con el objetivo de ampliar las disponibilidades de oro, comenzaron pronto a aplicar la mayor producción a lucrativas operaciones de carácter comercial y financiero. Es decir que las tradiciones, hábitos $\mathrm{y}$ actitudes acumuladas y transmitidas a través de los rudimentarios sistemas de la Colonia entraron a ejercer posteriormente un papel clave al actuar simultáneamente como factores que hacian posible ensanchar la oferta metálica y como un impulso a la demanda de ese mismo oro, para desarrollar en más amplia escala las actividades en que se había obtenido una ventaja comparativa, basada quizá en la experiencia, en la lucha por la supervivencia y en el consiguiente proceso selectivo. Después de varias generaciones de brega con el fiado a los mazamorreros, se convirtieron los antioqueños en los financistas del Estado colombiano y de los empresarios capitalinos. Asimismo, de rescatantes pasaron a ser los monopolistas del comercio de importación en el occidente colombiano y los grandes intermediarios de la economía tabacalera.

Hacia 1830 consideraban ya algunos que los antioqueños eran los principales comerciantes de importación en el país. Las mercancías inglesas se distribuían con amplias ganancias en mercados tan remotos como Popayán y Quito. En buena parte se aprovechaban algunas facilidades del comercio de depósito de Jamaica, tales como el finan-

107 Latorre Mendoza, op. cit., pp. 301-307.

108 Vicente Restrepo, op. cit., p. 93.

109 Op. cit., p. 55.

110 Mörner, op. cit., pp. 329-331.

111 Vicente Restrepo, op. cit., pp. 96-97. 
ciamiento otorgado por los comerciantes de la Isla, la aceptación del pago en oro en polvo y las mayores posibilidades del contrabando, tanto para la salida del oro como para la introducción de las mercancías.112 Otra ventaja del comercio de depósito con Jamaica eran sus importantes economías en el transporte.113 Algunas casas comerciales antioqueñas establecieron sus oficinas en Jamaica y en Inglaterra y durante algún tiempo actuaron como los únicos comisionistas de otros importadores colombianos en Europa. ${ }^{114}$ E1 comercio exterior se complementaba mediante un considerable intercambio con otras regiones del país, y era así como los textiles de algodón del Socorro, las ropas de lana de Boyacá y las barras de hierro de Cundinamarca procesadas en el Socorro para la fabricación de herramientas agrícolas y mineras, encontraron en Antioquia un mercado significativo ${ }^{115}$ al lado de productos agropecuarios como ganado vacuno, cerdos, mulas y cacao, ${ }^{116}$ llevados desde el valle del Cauca, la costa Atlántica $\mathrm{y}$ en ocasiones de los llanos orientales.

El nuevo enlace entre la minería y el comercio fortificaba obviamente los ingresos y las potencialidades de acumulación capitalista, pero a diferencia de lo que había ocurrido en la base medieval de las economías urbanas comerciales de los países europeos, el nivel de ganancias de los empresarios no era un factor tan determinante de los ingresos globales de la colectividad ni una pieza tan central y eficiente del engranaje económico regional. En la ciudad europea buena parte de los gastos de los comerciantes se localizaba en productos y servicios de tipo artesanal de procedencia local, cuya remuneración a su turno estimulaba los mercados de la producción rural circunvecina. ${ }^{117}$ El factor multiplicador entre ingresos de comerciantes y dueños de minas e ingreso social era sustancialmente menor en Antioquia, como resultado de fuertes filtraciones a través del consumo de bienes importados por las clases acaudaladas y de las inversiones hechas fuera de la región. Negocios de tabaco, empréstitos, compañías de transporte y emigración de empresarios hacia Bogotá fueron ejemplos usuales de este último fenómeno, que a veces se veía intensificado por razones de inseguridad política. Por ejemplo, hacia 1880 Núñez se quejaba de que con dineros antioqueños se hubiese fundado un banco en Centroamérica, ${ }^{118}$ a donde emigraron además algunas familias pudientes y emprendedoras.

Lo anterior no significa ni mucho menos que el desarrollo mineró y comercial hubiese carecido de vínculos importantes con el resto de la economía antioqueña. Por una parte, la vigencia de una demanda muy elástica de oro permitía la coexistencia indefinida de la minería capi-

112 Mörner, op. cit., pp. 320-323. Mollien, op. cit., pp. 423-424.

113 Una explicación del fenómeno se encuentra en Miguel Samper, op. cit., Vol. 1, p. 36 .

114 Latorre Mendoza, op. cit., p. 165; Safford, op. cit., pp. 64-68.

1.15 Frank Safford, Commerce and Enterprise in Central Colombia, 1821-1870. Disertación doctoral inédita. Microfilm, 1964, p. 102.

1116 Ospina Vásquez, op. cit., pp. 220-221.

117 Celso Furtado, Desarrollo y subdesarrollo, Buenos Aires, Editorial Universitaria, 1964, pp. 124-132.

118 Rafael Núñez, La reforma politica en Colombia. Bogotá, Biblioteca Popular de Cultura Colombiana, 1944, pp. 88-89. 
talista y de los sistemas tradicionales de búsqueda de oro, presentándose así notorias diferencias con respecto a la experiencia típica de los países europeos durante la revolución industrial, en los cuales la artesanía fue rápidamente desalojada por una producción más eficiente y barata. En Antioquia el grupo de los mazamorreros seguía representando hacia 1880 las tres cuartas partes del personal minero.119 En segundo lugar, y a pesar de la fuerte incidencia de los consumos importados, fue desarrollándose un modesto sector artesanal, en buena parte inducido por los estratos sociales medios como los de agricultores y mineros autónomos. En el censo de población de 1869 el número de artesanos antioqueños era ya superior al de los mineros y al đe sirvientes, y significaba el segundo renglón de empleo en el estado, đespués de la agricultura. La participación de ambos sexos en el artesanado era además muy equilibrada. ${ }^{120}$ En tercer lugar, la orientación que dio la élite burguesa desde las posiciones de gobierno a la activiđad económica regional tuvo indudables efectos benéficos. No sólo fue estimulado el movimiento de colonización a través de una nueva política agraria, sino que también se crearon en algunos períodos incentivos diversos al desarrollo agrícola. Así por ejemplo, entre 1830 y 1840 la iniciativa oficial facilitó la explotación de plantaciones de cacao en gran escala, la introducción del cultivo de la papa en las regiones de clima frío y el uso de pastos artificiales y de mejores variedades de caña de azúcar. ${ }^{121}$ Aunque algunos de estos logros fueron efímeros, como ocurrió en el caso del cultivo del cacao en Santa Fe de Antioquia, los nuevos incentivos reflejaban una política agrícola mucho más acertada que la de los reformadores españoles medio siglo atrás. La principal diferencia entre ambos enfoques consistió en que mientras las autoridades de la Colonia diluyeron sus esfuerzos en una amplia gama de productos con minúsculos mercados, los empresarios republicanos comprendieron mejor la ventaja de concentrar el esfuerzo en un número reducido de productos con buena base de demanda.

Para una mejor comprensión del desarrollo histórico del movi. miento empresarial antioqueño durante el siglo XIX conviene tener presente que, a pesar de la ampliación de las importaciones que sobrevino a raíz de la Independencia, hay alguna evidencia estadística de que durante un período que se extendió hasta la época del auge tabacalero, el valor total en pesos oro de las mercancías introducidas al país no marcó una tendencia notoria de alza a través del tiempo y estuvo sujeto a fuertes fluctuaciones periódicas. ${ }^{122}$ Este estancamiento de las importaciones del país estuvo obviamente ligado, por una parte, a las limitaciones del desarrollo de las exportaciones y a las necesidades de atender la demanda interna de oro, tanto por parte del Estado como de los particulares; y por otra, a la fuerte concentración de los ingresos monetarios de la población colombiana en unas pocas personas, lo cual implicaba que una parte muy grande de las rentas derivadas del comercio y de la minería quedase en manos de los propios

119 Von Schenck, op. cit., p. 30.

120 Anuario estadístico de Colombia. Bogotá, Imprenta de Medardo Rivas, 1875, p. 22.

121 Alvaro Restrepo Euse, op. cit., p. 228.

122 Nieto Arteta, op. cit.; Ospina Vásquez, op. cit., p. 146. 
empresarios. Esa constricción al comercio de importación frenaba la reinversión de las ganancias normales en el mismo negocio, y sobrevino así una acumulación de capitales en manos de los importadores, quienes buscaban entonces su colocación en nuevas actividades. De éstas, la más inmediata fue la financiera, en la cual el comerciante contaba además con la experiencia derivada de la arraigada práctica antioqueña de ventas al fiado. Desde los comienzos del régimen de Santander, los antioqueños jugaron un papel crucial tanto en el suministro directo de fondos al Estado como en la gestión de empréstitos externos, ${ }^{123}$ de la cual derivaron grandes beneficios económicos directos y una influencia poderosa en los medios gubernamentales de Bogotá para lograr futuros privilegios y concesiones. ${ }^{124}$ Sin embargo, en algunas ocasiones las relaciones financieras con el gobierno central fueron muy desfavorables para los capitalistas de Medellín, en particular en el caso de los empréstitos forzosos exigidos por el general Mosquera. ${ }^{125}$

La gestión financiera de los antioqueños no se limitó al radio de acción oficial. La escasez de fondos privados en Bogotá y la vigencia de una tasa de interés más alta en la capital que en Medellín atrajeron hacia aquella fondos líquidos antioqueños, hasta el momento en que se fundaron establecimientos bancarios apoyados por la legislación. Entre tanto, en las palabras del historiador Safford, Medellín fue el banquero de Bogotá.126 Cuando el gobierno central autorizó hacia 1870 la creación de servicios bancarios privados, algunas de las principales casas importadoras de Medellín emitieron circulante fiduciario que tuvo amplia aceptación dentro del estado de Antioquia y estimuló poderosamente el comercio regional. Von Schenck relata un episodio muy interesante acaecido algunos años después de iniciarse este sistema cuando, por motivo de perturbaciones políticas, el papel fiduciario fue devuelto masivamente para su conversión en oro, en momentos en que la casa emisora carecía de los recursos necesarios para atender a la crisis. Conscientes del peligro que tendría una bancarrota para la confianza del público y el ritmo de los negocios, la comunidad comerciante de Medellín se movilizó para respaldar a los banqueros, aportando el oro de que disponían y salvando así la situación. Este episodio ilustra no sólo el control efectivo de los recursos financieros de la región por parte del grupo de comerciantes, sino también el grado de interdependencia y de solidaridad que se había desarrollado entre ellos.127 De otro lado, no conviene perder de vista que para esa época la capacidad importadora del país había crecido apreciablemente con respecto a la situación reinante en los primeros tres decenios del período republicano, y que la utilización efectiva de esa mayor capacidad dependía en buen grado de una suficiente elasticidad monetaria interna.

Sin embargo, en periodos de estancamiento de las importaciones, el comerciante poderoso no sólo no estaba en capacidad de ampliar la escala de las actividades mercantiles por medio de la colaboración

123 Bushnell, op. cit., pp. 119, 138-141.

124 Safford, Significación de los antioqueños..., p. 67.

125 Ibid., pp. 55-56; Latorre Mendoza, op. cit., pp. 181-183.

126 Safford, Commerce and Enterprise in Central Colombia, 1821-1870, p. 391.

127 Von Schenck, op. cit., pp. 45-46. 
financiera a sus colegas de menos recursos, sino que además esa colaboración podría restarle parte de sus propios mercados. En tales circunstancias el interés fundamental del comerciante rico apuntaba más bien hacia el fortalecimiento de su posición vendedora en un mercado de dimensión predeterminada, es decir, hacia el logro de ventajas monopolísticas de una u otra especie. Ninguna de esas ventajas era más estratégica que la del control de los sistemas de transportes, el cual fue logrado por unas pocas casas importadoras de origen antioqueño a través de inversiones en empresas de navegación en el río Magdalena y en uno de sus caminos accesorios. ${ }^{128}$ Esas empresas contaron con el apoyo oficial y suscitaron enconadas controversias entre el gremio de comerciantes. ${ }^{129}$ Pero desde el punto de vista de los favorecidos, una política financiera de esa clase tendía a integrar el control de las distintas etapas del complejo mercantil, incrementaba la eficiencia del sistema, abría nuevos frentes de utilización del capital acumulado $\mathrm{y}$, al diversificar riesgos en varias actividades, propendía hacia un mejor equilibrio financiero del capitalista.

No obstante, el proceso de diversificación de actividades durante un período de incipiente experiencia empresarial operaba como peligrosa arma de dos filos. Si desde el punto de vista del inversionista la fragmentación del capital resultaba lógica y eficiente, lo contrario ocurría con respecto a la subdivisión de las escasas capacidades directivas en oficios no sólo diferentes sino cada vez más complejos. En más de una ocasión los riesgos generados por la menor eficacia de la gestión empresarial resultaron fatales para la marcha de la empresa. Antes de dar algunos ejemplos al respecto, conviene situar el problema dentro de un marco de referencia más general. En las primeras etapas de una economía capitalista, el empresario innovador ha sido la persona que, disponiendo de medios de control de los factores productivos, percibe y aprovecha la posibilidad de combinarlos de un modo más eficiente que los rutinarios, tarea a la cual decide aplicar tanto su capital como su capacidad de trabajo. Control financiero y manejo directivo del negocio aparecen inicialmente como manifestaciones inseparables del papel empresarial. De allí en adelante, y a medida que la economía se desarrolla en forma cada vez más compleja, surgen las ventajas de las operaciones en gran escala, las técnicas financieras elaboradas y la presencia de gerentes profesionales especializados. En ese momento la disociación del capitalista y del director de la empresa resulta ventajosa, cosa que no es cierta en etapas más primitivas. ${ }^{130}$

Para comprender mejor este último punto, coloquémosnos en el contexto de una economía mercantil en la que los recursos líquidos crecen en un período más o menos corto en una proporción mayor que la disponibilidad de recursos empresariales, lo cual parece haber ocurrido en Antioquia como consecuencia de una importación más bien fácil de la tecnología minera utilizada por los europeos. Si la actividad básica de esa economía, en nuestro caso el comercio de importación, está limitada en su crecimiento por razones exógenas pero entre tanto reporta un margen apreciable de ganancias para el empresario, éste

128 Safford, op. cit., pp. 309 ss.

129 Miguel Samper, op. cit., Vol. 1, pp. LV, LVI.

130 Joan Robinson, op. cit., p. 6. 
se encuentra ante la disyuntiva de acometer nuevos frentes de trabajo para utilizar el capital sobrante, exponiéndose así a reducir los rendimientos de la totalidad de su capital, por las limitaciones en los recursos empresariales, o divorciar prematuramente la dirección de la propiedad de la empresa. Ningún ejemplo más ilustrativo y trágico de los perjuicios de la primera alternativa que la experiencia de algunas firmas antioqueñas en las exportaciones de tabaco hacia mediados del siglo. La segunda alternativa, cuyos efectos fueron menos protuberantes pero a la larga no menos deletéreos, está ilustrada por la propia historia de las explotaciones de la minería de veta.

Los cambios institucionales asociados al auge de las exportaciones de tabaco que se inició a partir de 1845 han sido objeto de viva controversia por parte de apologistas y detractores de la política económica liberal impuesta por los gobernantes neogranadinos de mediados de siglo. Para unos, la eliminación del tradicional monopolio estatal fue una movida maestra que liberó poderosas fuerzas productivas antes encadenadas por la ineficiencia de sistemas arcaicos. Para otros, el traslado de la industria tabacalera a manos de la iniciativa privada no sólo cercenó la fuente principal de ingresos fiscales, sino que además desató una fiebre especulativa en la que los intereses de corto plazo estuvieron contrapuestos a un firme desarrollo de la industria, que en el lapso de tres decenios desapareció como ramo exportador significativo. ${ }^{131}$ Más que replantear esta polémica nos interesa aquí discutir algunos rasgos característicos de la conducta empresarial de los exportadores de tabaco dentro del contexto económico de la época, para comprender en mejor forma las desventajas y serios riesgos a que estuvo expuesto nuestro primer ensayo de participación en gran escala en los mercados internacionales.

Las razones para abolir el monopolio no fueron exclusivamente de orden ideológico. A pesar de que el Estado percibía importantes ingresos por la diferencia entre precios de venta y precios de compra de la hoja, esa diferencia, después de descontar gastos de compra, empaques, nómina de factorías y transporte a los centros de consumo, no dejaba una utilidad neta suficiente para financiar por sí misma las compras de la próxima cosecha. ${ }^{132}$ Como además el fisco afrontaba con frecuencia una situación deficitaria, ha debido ocurrir que las utilidades líquidas del monopolio, al ser incorporadas a los fondos comunes, fuesen drenadas por un alto volumen de gastos generales, colocando en situación aun más precaria las bases financieras del ciclo productivo. De allí que desde 1835 varios ministros de Hacienda hayan reiterado en sus memorias la opinión de que la falta de medio circulante estrangulaba las posibilidades de desarrollar los cultivos. ${ }^{133}$ Como simultáneamente los comerciantes afrontaban un nivel estacionario

131 El primer punto de vista estuvo representado por algunos escritores liberales de la época como Miguel Samper (op. cit., Vol. 1, pp. 35-37) y Salvador Camacho Roldán (Memorias, Tomo II, Bogotá, Biblioteca Popular de Cultura Colombiana, 1946, pp. 28-39), siendo este último más ecléctico en sus apreciaciones. Ver también Nieto Arteta, op. cit., pp. 241-275. Una fuerte crítica a la eliminación del estanco del tabaco se encuentra en Indalecio Liévano Aguirre, El proceso de Masquera ante el Senado. Bogotá, Editorial Populibro, 1966, pp. 30-34.

132 Camacho Roldán, op. cit., pp. 22-23.

133 Nieto Arteta, op. cit. 
en las importaciones, resulta muy lógico que ellos mismos hayan ejercido una fuerte presión para que se trasladase a sus manos el mercadeo de la hoja. En esta forma se encontraba simultáneamente un canal adicional de inversión de capitales, inaprovechable para el gobierno, y se mejoraban las posibilidades de abrir mercados externos que por ese entonces ya comenzaban a aceptar los tabacos neogranadinos. Esto a su turno redundaría sobre la capacidad importadora del país, en cuya utilización estaban los mismos comerciantes particularmente interesados. ${ }^{134}$

Cuando en 1846 el gobierno reemplazó el tradicional sistema de cosecheros matriculados por contrato de producción en las principales factorías tabacaleras, comerciantes antioqueños obtuvieron las concesiones de Ambalema y Palmira. La primera de ellas alcanzó en realidad a dominar por algún tiempo la industria nacional y a concentrar casi la totalidad de las exportaciones. ${ }^{135}$ Esta concesión contaba con ventajas muy importantes como las facilidades de transporte, los contactos comerciales y financieros ya establecidos por la casa de Montoya, Sáenz y Cía. en Europa para sus negocios de importación, los grandes recursos de la firma para aprovechar algunos remates de inventarios y el acceso a las mejores tierras de cultivo en ese entonces. A pesar de esas ventajas, aun firma tan poderosa no alcanzó a desarrollar suficiente organización y adecuado control de la producción que le permitiese mantener su posición en el mercado sin graves riesgos. Algunas políticas de precios tendientes a desalentar la producción de calidades superiores, grandes inversiones en tierras diferentes a las dedicadas al cultivo del tabaco, mientras éstas eran acaparadas por unos pocos propietarios, ausentismo temporal del país por parte de Ios socios, etc., son algunos síntomas de que la principal firma exportadora de tabaco en el país tenía aún puntos muy débiles de su gestión empresarial cuando después de sólo cinco años de transición entre el estanco oficial y la libre iniciativa privada, las fuerzas de la competencia desencadenaron una lucha intensa por el control de la tierra y de la mano de obra entre las firmas capitalistas que afluyeron sobre la zona de Ambalema para desarrollar la exportación. .3* $^{3 *}$

Este nuevo régimen de libre competencia por los factores de la producción, superpuesto a condiciones inciertas y fluctuantes en el precio de los mercados internacionales, colocaba a la industria tabacalera en franca desventaja con respecto a un vendedor organizado en forma monopsonística en los mercados internos de trabajo y de terrenos de cultivo, como parece haber sido el caso de las plantaciones holandesas en Java y Sumatra. ${ }^{137}$ En primer lugar, no existían entre nosotros las premisas institucionales indispensables para el cumplimiento de las reglas del juego de un mercado competitivo, en especial en lo que se refiere a la fuerza legal de los contratos entre cosecheros y terra-

134 La presión del grupo importador para lograr la eliminación del estanco de tabaco se manifestaba ya en la prensa santafereña hacia 1835 . Véase Safford, op. cit., p. 194.

135 John P. Harrison, The Colombian Tobacco Industry: From Government Monopoly to Free Trade, 1778-1876. Disertación doctoral inédita. Universidad de California, 1951, microfilm, pp. 265-275.

136 Safford, op. cit., pp. 219 ss.

137 Harrison, op. cit., pp. 281-282. 
tenientes o entre éstos y los exportadores. Esta sola circunstancia jugó un papel decisivo en la quiebra de la firma Montoya y Sáenz, como ha sido demostrado recientemente por el historiador Safford. ${ }^{138}$ En segundo lugar, en un régimen de monopsonio de los factores productivos, el empresario ajusta su escala de operaciones en tal forma que su objetivo de máximas ganancias le reporta un margen que no es vulnerable a la presión de competidores sobre recursos más o menos fijos. En el lenguaje del análisis económico moderno, el monopsonista contrata factores de la producción hasta el punto en que el costo marginal sea igual al ingreso marginal esperado, así que para una industria sometida a costos crecientes, como era el caso de las plantaciones de Ambalema, ${ }^{139}$ resultaba una diferencia entre precio de venta anticipado y costo medio que permitía compensar fluctuaciones imprevistas en el mercado internacional entre el momento de la contratación de la cosecha y el momento de su venta. ${ }^{140}$ Cuando esa diferencia la mermaban las fuerzas inherentes a una organización competitiva de los mercados internos, el empresario que no alcanzaba a prever tales fluctuaciones (que según Safford Ilegaron a ser del $25 \%$ o más) estaba en realidad jugando a la ruleta rusa, en la que perecieron por lo menos otras cuatro casas exportadoras, aparte de terratenientes poderosos que se dieron a la especulación. ${ }^{141}$

En tercer lugar, una industria competitiva tendía a operar a una escala global tanto mayor que la correspondiente a otra monopsonística con iguales mercados de venta, cuanto más se intensificaba la diferencia entre sus costos marginales y los medios, ${ }^{142}$ y cuanto más elástica era la demanda. En un mercado internacional que no discriminó inmediata y drásticamente la calidad del producto, como ocurrió en nuestro caso en las plazas de Londres y de Bremen, este fenómeno contribuyó a estimular en una primera etapa la proliferación de calidades inferiores, tanto más probables en el área de Ambalema, en donde apenas una minoría de las tierras eran de óptima condición para los cultivos de tabaco. ${ }^{143}$ Cuando en una segunda etapa el mercado internacional registró esas diferencias de calidad, y aun antes, cuando la propia casa de Montoya y Sáenz estuvo operando en el régimen de mercado libre de capitales y quiso conservar los mejores suministros de la región el nivel de ganancias del exportador, tendió a reducirse al insostenible rasero de las calidades inferiores, percibiendo los dueños de las mejores tierras el obvio e históricamente comprobado usufructo de las rentas diferenciales. ${ }^{144}$

138 Safford, op. cit.

139 Estos costos crecientes con respecto a la escala de producción provenían de la disponibilidad limitada de tierras de buena calidad y de mano de obra. Sobre los efectos de la expansión de la industria en el nivel de los jornales y de los precios de la tierra a partir de 1850, véase Camacho Roldán, op. cit., pp. 33-34. También tomo I, p. 167.

140 Un análisis técnico de la conducta empresarial en condiciones de mercado incierto se encuentra en Fritz Machlup, The Economics of Sellers' Competition. Baltimore, Johns Hopkins Press, 1952, pp. 228-236.

141 Camacho Roldán, op. cit., pp. 32-33.

142 Joan Robinson, The Economics of Imperfect Competition. Londres, Macmillan, 1954, pp. 218-228.

143 Harrison, op. cit., pp. 274-277.

144 Safford, op. cit., pp. 227-228. 
Muchos otros factores contribuyeron a dar por terminado este episodio, que Nieto Arteta llamó la mascarada económica de nuestro siglo XIx. La guerra civil de $1860,{ }^{145}$ las sequías, las enfermedades de la planta, el desgaste final de las mejores tierras, ${ }^{146}$ los cambios de la política aduanera alemana, etc., remataron una situación fatal por sí misma. En síntesis, la débil experiencia de aventurados empresarios antioqueños como los Montoya, los Sáenz, los Posada, los Muñoz, los Vélez, los Uribe, etc., había tenido minúscula probabilidad de sobrevivir dentro de un régimen politicoeconómico que quiso dar en cinco años el tránsito de economía feudal a economía de libre competencia. El período intermedio, que en Europa lo representó el mercantilismo durante no menos de dos siglos de protección y vitalización empresarial, se vio brutalmente atrofiado por las veleidades de una ideología de dudosa autenticidad histórica. En marcado contraste con nuestra temprana orientación manchesteriana, los empresarios brasileños del hacia afuera, comenzaban por la misma época a organizar su economía de exportaciones cafeteras en un amplio frente que comprendía el pleno control de las tierras, el reclutamiento de mano de obra dentro y fuera del país, la organización de la producción, las etapas de mercadeo y la abierta interferencia en la política económica del gobierno.

E1 desenvolvimiento de la minería de veta en Antioquia durante el siglo XIX quedó históricamente documentado desde la clásica obra de Restrepo..$^{147}$ De su relato queda claro el hecho de que, a pesar de que la iniciativa de capitalización y tecnificación de la industria fue puesta en movimiento por un grupo empresarial con amplios objetivos económicos, la gestión administrativa de las nuevas empresas fue dejada en manos con frecuencia poco competentes. Así fue como sólo unas pocas minas fueron explotadas de acuerdo con la nueva tecnología y en algunas el personal técnico era escaso y aun de dudosa calidad. En efecto, se dieron casos notorios de escogencia inadecuada de los equipos u otras formas de desaprovechamiento de capital y de inercia frente a cambios minerológicos dentro de un determinado yacimiento, que exigían radicales sustituciones tecnológicas. Al no ser éstas implementadas oportunamente se produjeron pérdidas operativas y aun el abandono temporal de la explotación y la quiebra de los propietarios. Las demandas excesivas de éstos sobre la capacidad financiera de la empresa crearon también graves problemas. En una palabra, en tanto que los empresarios fueron audaces y demostraron gran visión en la concepción de la nueva minería, los administradores fueron descuidados e ineficientes, independientemente de su origen nacional o extranjero.

Este fenómeno provocó sucesivos traslados de la propiedad minera hacia grupos inversionistas de precaria habilidad empresarial y de mentalidad decididamente rentista, dentro de los cuales llegaron a desarrollarse pautas extravagantes de consumo en las épocas de bonan-

145 Samper, op. cit., vol. I, p. 37.

146 Sobre este último factor enfatizado por Camacho Roldán, op. cit., el historiador Harrison llegó a formular una interesante crítica (op. cit.). dice $\mathrm{A}$. 
za además de reducida capacidad de explotación en circunstancias adversas. La historia de la famosa mina del Zancudo fue el caso más conspicuo de este estado de cosas, pero algo parecido llegó a ocurrir con la del Silencio y la de Bolivia, a juzgar por el relato de Restrepo. De tal manera que esta disociación de los frentes administrativo y empresarial abrió fuerte brecha al circuito económico de la minería capitalista y restó mucho impulso al proceso de acumulación de capitales por ese canal. No es, pues, de extrañar que la burguesía moderna de Antioquia se haya formado más en el comercio tanto cafetero como de importación, que en las actividades propiamente mineras.

La crisis de la minería colonial había deprimido, en efecto, el valor de la propiedad minera desde comienzos de la República y dio lugar a compras de ocasión por parte de los inversionistas que alcanzaron a percibir las posibilidades de una empresa basada en el capital y en la técnica. En esta forma se manifestaba la primera condición de acumulación de riqueza en manos de una burguesía en ascenso. Además, las condiciones técnicas hacían en un principio posible la realización de ganancias de capital, que vinieron a frustrarse por la deficiente organización de aquel capitalismo primitivo, que impidió que la minería de veta se convirtiese en un genuino motor de la economía antioqueña, al tiempo que la hizo vulnerable a la penetración de capitales extranjeros. El golpe de gracia a la iniciativa local fue dado posiblemente cuando, a fines del siglo, la legislación monetaria impuso la paridad retroactiva de un superabundante papel fiduciario, con respecto al pago de los préstamos hechos en oro por los capitalistas mineros a los inversionistas en otras actividades. ${ }^{148}$ Este episodio, que merece en realidad una detenida investigación económica y social, hubiera podido contribuir a impulsar otras actividades como la cafetera y la industrial, al tiempo que habría facilitado el predominio del capital extranjero (en parte inmune a este fenómeno de la devaluación del metal) en las nuevas actividades de la minería de aluvión que se iniciaron en Antioquia hacia esos años. ${ }^{14 !}$

Así, entre 1880 y 1900 convergen varios hilos de la historia económica de Antioquia hacia fenómenos de conspicua transición del desarrollo regional, cuyo análisis elaborado parece ser requisito indispensable de un estudio de los procesos sociales del siglo xx. La trama subyacente a esos cambios estuvo radicada naturalmente en los fenómenos sociopolíticos del movimiento de regeneración de Núñez y en la consiguiente tendencia a formas más centralistas y nacionalistas de gobierno. Pero en torno a ella se manifestó toda una constelación de fenómenos económicos. En primer lugar, las formas individualistas de colonización reemplazaron definitivamente las modalidades de tipo colectivista, al tiempo que el advenimiento del cultivo cafetero arraigó a la tierra a los grupos campesinos emigrantes, que antes habían mostrado rasgos de definido nomadismo. En segundo lugar, la misma industria cafetera desplazó el centro de gravedad de la agricultura antes localizado en las actividades de subsistencia, hacia una economía de mercado que, al ser vitalizada por mejores vías de co-

148 Antonio José Restrepo, "Tomás Carrasquilla", en Tomás Carrasquilla, Obras completas. Medellín, Editorial Bedout, 1958, vol. 1, p. xviii.

149 Parsons, op. cit., p. 59. 
municación, ofreció buenas oportunidades al desarrollo manufacturero. En tercer lugar, el control de la distribución de las mercancías importadas con destino al valle del Cauca y al Cauca, que antes estaba en manos de los comerciantes antioqueños, desapareció cuando en Cali surgieron firmas mercantiles estimuladas por las mejores facilidades de comunicación con el Pacífico. En cuarto lugar, se registraron radicales cambios en la industria minera, ya comentados. Y finalmente, al terminar la guerra de los Mil Días, se sentaron bases de estabilidad política que permitieron el desarrollo de la actividad económica en una forma más ordenada y menos interrumpida por los recurrentes traumas que trajeron consigo los conflictos políticos del siglo anterior. Todas esas fuerzas parecen haber contribuido a configurar, en una $u$ otra forma, la coyuntura histórica a partir de la cual se inició el movimiento de industrialización en Antioquia. La dinámica misma de esa configuración y de su posterior desarrollo está más allá del alcance del presente ensayo.

\section{COMENTARIO SOBRE ALGUNAS INTERPRETACIONES ALTERNATIVAS DEL CASO ANTIOQUEÑO}

\section{a) Introducción}

Los temas de la colonización y de la evolución empresarial en Antioquia han sido objeto de estudio sistemático por parte de varios científicos sociales norteamericanos, quienes se han sentido atraídos por la naturaleza atípica de este caso de desarrollo. En las distintas maneras como ellos han interpretado los materiales históricos disponibles, se observa un rasgo común a los enfoques del economista, del sociólogo y del geógrafo, rasgo que por lo demás no está ausente en las creencias y en el folklore mismo del pueblo antioqueño. En una u otra forma el grupo social llega a ser descrito como una minoría dentro de la nacionalidad colombiana, caracterizada por sus condiciones de igualdad social, de confianza en sí misma y de ánimo por el trabajo. Las modalidades psicológicas del antioqueño han llegado a tomarse con frecuencia como dato fundamental que, agregado a las tradiciones de independencia personal y de propensión al riesgo alimentadas por la prolongada experiencia de la minería, se considera suficiente para explicar el comportamiento socioeconómico revelado en distintas etapas históricas.

Menos atención se ha concedido a la naturaleza peculiar de aquellas fuerzas externas que condicionaron sucesivas decisiones críticas con respecto a las combinaciones de los recursos económicos y a los sistemas de control social. Asimismo podría decirse que no se han analizado suficientemente aquellos procesos de aprendizaje y de acumulación de experiencias que se conformaron gradualmente en renovadas respuestas a las condiciones mutables de la constelación de recursos productivos.

El gran economista antillano Arthur Lewis ha dejado implícita en varios de sus estudios la idea de que el desarrollo económico es fundamentalmente un proceso creativo y que, como tal, es tan poco susceptible de ser reducido a explicaciones racionales como podría serlo 
un fenómeno de expresión artística. Según este pensamiento, todo intento de hacer inteligible la dinámica del cambio económico está sujeto a desembocar tarde o temprano en actos y situaciones inescrutables, en los cuales el intelectual no alcanza a ver sino manifestaciones primarias de energía social. De ser esto cierto, los modelos psicológicos deterministas del desarrollo socioeconómico tendrían los mismos riesgos de abstracción y de simplificación que las conocidas y enrarecidas construcciones conceptuales que giran en torno a los atributos ideales del homo oconomicus.

No parece factible concebir las reacciones eficaces de un grupo social a los retos ambientales como actos predeterminados por leyes inmutables, a menos que esos actos sean referidos a un marco mental tan amplio como para abarcar la infinidad de reacciones que pueden ser suscitadas por condiciones externas esencialmente cambiantes. La tarea del historiador económico se vuelve más prometedora cuando se intentan reconstruir los ingredientes esenciales de aquellos episodios que se juzgan haber tenido particular influencia sobre los grandes trazos del proceso de desarrollo, para luego esclarecer el alcance y el significado de las reacciones específicas que manifestaron los agentes económicos, dentro del marco de escogencia que les determinó cada uno de aquellos episodios concretos.

Este último ha sido el enfoque adoptado en nuestro ensayo, y con referencia a él nos permitiremos hacer algunos comentarios sobre tres conocidos estudios acerca del mismo tema.

\section{b) La visión del geógrafo Parsons}

El tratado de Parsons es la obra clásica sobre la colonización antioqueña, y contiene además una visión general de la historia económica de Antioquia desde los tiempos de la Conquista española hasta la mitad del siglo xx. Es indudable que ese trabajo constituye un marco insustituible de referencia para cualquier estudio posterior y que ofrece la mejor selección de fuentes históricas de que hoy disponemos. A pesar de que Parsons es fundamentalmente un geógrafo, debemos a él algunas claves tan interesantes como discutibles sobre el análisis económico del movimiento colonizador. El siguiente es un resumen de sus opiniones sobre las causas que motivaron el temprano quebrantamiento del latifundio en Antioquia:

Para resumir: la extrema parcelación de las tierras de la colonización antioqueña reciente debe interpretarse a la luz de los orígenes de su ocupación. Únicamente el antiguo macizo mediterráneo Rionegro-Medellín-Santa Rosa estaba efectivamente incorporado en la estructura colonial; y aun aquí mismo, la extrema insistencia en la minería y la naturaleza esparcida de los depósitos no favorecían el desarrollo de las tradiciones profundamente arraigadas, que provenian de las haciendas agrícolas y de ganado de levante en otras partes de la Nueva Granada. En Antioquia, los derechos mineros tuvieron siempre precedencia sobre los derechos agrícolas; de tal manera que, en efecto, todas las tierras que no eran cultivadas inmediatamente han sido abiertas a la explotación por los poseedores de derechos de minas. Y esta explotación, además, ha sido siempre en función de trabajo libre porque en los tiempos coloniales el suministro de indios y de 
negros esclavos era insuficiente. El concepto de riqueza, entonces, no estaba vinculado a determinados pueblos y al suelo, sino más bien al trabajo duro y a la iniciativa. En las nuevas tierras volcánicas al sur y al oeste, la naturaleza profundamente quebrantada de la región, junto con el orgullo de los cultivadores de café y con el espíritu de autonomía libre e independiente, se combinaron para producir este caso rarísimo de una sociedad democrática de pequeños propietarios, en un continente dominado por un latifundismo latino tradicional, 150

Algunos puntos de esta interpretación merecen comentario. En primer lugar, el origen reciente del poblamiento de las regiones del sur y del suroeste de Antioquia, es decir, la ocupación de las mismas cuando ya había terminado el régimen colonial, no parece tener un peso suficiente como factor explicativo del hecho de que los colonizadores antioqueños se hayan liberado tan eficazmente de las viejas tradiciones hispánicas. En realidad la historia demostró que las condiciones institucionales para la consolidación de los latifundios en América Latina fueron por lo menos tan favorables después de la independencia como bajo el imperio español. Este punto ha sido ampliamente documentado en muchos estudios de la historia social latinoamericana y, como lo ha destacado el profesor Albert Hirschman, lo que es particularmente interesante en torno al caso de la colonización del occidente colombiano es que durante aquellos años en que las nuevas tierras de cultivo fueron abiertas al cultivo del café por un gran número de campesinos independientes, las regiones rurales de México experimentaban simultáneamente un extraordinario proceso de concentración de la propiedad agraria en unos pocos latifundios amparados por la autoritaria administración de Porfirio Díaz. ${ }^{151}$

Debe agregarse además que, como el propio Parsons lo reconoció e ilustró muy lúcidamente en su obra, hubo muchas tierras con títulos de propiedad derivados de la época colonial, que fueron ocupadas por olas de colonos en distintos períodos del siglo XIx. Éstas fueron las tierras clasificadas en la primera categoría de tenencia agraria en nuestro cuarto capítulo, que por lo demás constituyen el caso más interesante de análisis de conflicto social y de investigación de las fuerzas económicas que contribuyeron a configurar el compromiso final entre propietarios y colonos.

La evidencia histórica suscita también algunas dudas en torno al segundo punto de la interpretación de Parsons. La naturaleza dispersa de los depósitos auríferos en las zonas de poblamiento más antiguo no parece haber impedido el desarrollo de los grandes latifundios y, por el contrario, hay algunas pruebas de que hubiese operado en la dirección opuesta. En el informe de Mutis y Delhuyar (citado en la p. 361) quedaba constancia de que la concesión de enormes extensiones de tierra había contribuido al atraso de la minería en Antioquia. Las concesiones de Quintana y de Villegas, mencionadas también por Parsons, fueron quizá los ejemplos más extremos de esta situación.

A este respecto parece que en la argumentación de Parsons no haya quedado suficientemente destacado el hecho de que a través de los

151 Albert O. Hirschman, Journeys Toward Progress, op. cit., pp. 93 ss. 
intersticios de esas grandes concesiones pudo filtrarse una masa de mineros independientes, que por su movilidad ejerció una peculiar presión contra las tradiciones de la propiedad agraria. Puede añadirse que cuando sobrevino el cambio tecnológico de la industria minera en Antioquia hacia 1830, la orientación de los empresarios sustituyó el énfasis tradicional sobre el uso extensivo de la tierra por uno nuevo de explotación intensiva del capital, deponiendo así una de las principales funciones de la gran propiedad agraria dentro del sistema económico regional. En otros términos, no fue la continuidad en los sistemas de combinación de recursos propios de la minería colonial, sino el fundamental cambio en los mismos, lo que vino a facilitar el nuevo tipo de agricultura característico del siglo xIX.

Un punto final de la interpretación de Parsons se presta a comentario. No parece muy adecuado decir que la minería de Antioquia había estado siempre explotada en función de trabajo libre, puesto que hasta un período avanzado de la dominación colonial española existieron cuadrillas de esclavos en muchas explotaciones. Por otra parte, parece necesario profundizar en las razones de la insuficiencia de los suministros de negros esclavos, por cuanto la industria minera del Cauca y del Chocó siguieron dependiendo de estos suministros hasta la época de la independencia. Parecería que este tipo de argumento contribuye más bien a oscurecer el proceso económico que tuvo lugar en el contexto de la minería colonial antioqueña. Como lo hemos sugerido en secciones previas de este ensayo, ese proceso parece haber estado caracterizado por un crecimiento desequilibrado entre minería y agricultura, afrontándose además serias limitaciones al comercio de víveres llevados desde otras regiones productoras que, junto con la tecnología rudimentaria y estacionaria dentro de la actividad minera, condujeron a una situación en la que el costo de subsistencia del esclavo llegó a ser más alto que sus rendimientos marginales en el trabajo. Este fenómeno habría inducido así la decadencia definitiva de la minería esclavista. ${ }^{152}$

\section{c) El enfoque psicológico de Hagen}

Otro investigador que ha prestado mucha atención al estudio del problema del cambio social en Antioquia es el economista Everett E. Hagen..$^{153}$ Su análisis está enmarcado en un cuadro teórico general cuya tesis esencial parece ser la de que "lá causa básica del cambio es la percepción, por parte de los miembros de algún grupo social, de que sus propósitos y sus valores vitales no son respetados por otros grupos de la sociedad a quienes los primeros estiman y reconocen

152 En un trabajo inédito (Property and Inequality in Precapitalist Societies, 1965) el profesor Mancur Olson ha desarrollado algunas ideas muy interesantes sobre la fundamentación económica de distintas formas de la propiedad en el seno de sociedades precapitalistas, con ayuda de algunos comentarios formulados por el profesor Evsey Domar sobre las causas de la esclavitud en Rusia y Estados Unidos antes de 1860. Estas ideas fueron de mucha utilidad para el autor, en su propósito de esclarecer algunos fenómenos sociales registrados en Antioquia en la segunda mitad del siglo xvir.

153 Hagen, op. cit. Las citas que siguen se han tomado de las pp. 185, 190, 206, $214,217,219,220,224,233$ y 235. 
positivamente". En el caso particular del grupo antioqueño, se habría desarrollado según Hagen una actitud de desprecio hacia tal grupo por parte de la élite terrateniente de Bogotá y Popayán que "miraba con condescendencia a los antioqueños, porque para explotar las minas de su región encontraron necesario tener que trabajar con sus propias manos". La percepción de este estado de cosas habría puesto en marcha una cadena de reacciones psicológicas en las gentes de Antioquia, que habría encontrado su expresión de una generación a otra en el contexto de un proceso dinámico que condujo finalmente al surgimiento del espíritu de empresa. Así habría aparecido inicialmente una actitud retraída, con rasgos de ansiedad y de rabia en contra de quienes "tenían tierra plana y rica" y "se burlan de nosotros porque sus propiedades les permiten disfrutar de la ociosidad".

Sobrevendría luego una erosión gradual de los valores sociales, a medida que "el hijo percibiría en alguna forma aún no verbalizada, que para su padre tenía gran importancia creer en la bondad de su ocupación y de su clase, como también en la bondad de las actitudes de los grupos sociales superiores, dándose cuenta además de que la ansiedad de su padre resultaba de la incompatibilidad de estas situaciones, lo cual le imposibilitaba seguir creyendo simultáneamente en ambas... El hijo probablemente internalizaría esa misma identidad social... pero junto con su penosa expectativa verá también un aspecto de la personalidad de su padre que estaba ausente en su abuelo, y que le sugerirá que el camino hacia la seguridad consiste en la represión de sus valores íntimos". La apatía, la inhibición y el conflicto interno reemplazarían la rabia y el orgullo, después de haber sido identificados éstos como sentimientos peligrosos. "Los antioqueños son ahora innovadores vigorosos, imaginativos y eficientes en toda Colombia, pero existen evidencias de que durante el siglo xvinI eran tenidos por inestables e irresponsables."

Pero "el retraimiento no es un callejón sin salida. A medida que se arraiga en generaciones sucesivas, va creando circunstancias de vida hogareña y de ambiente social propicias al desarrollo de una personalidad innovadora. La sucesión histórica parece ser: autoritarismo, deposición de la estima social, retraimiento y creatividad". Según Hagen, el tránsito del retraimiento a la creatividad sobreviene como resultado de cambios en la actitudes recíprocas entre los miembros de la familia, de una a otra generación. El hijo que observa la ansiedad de su padre comunicará más tarde a su propio hijo un sentimiento de compasión y de solidaridad, pero simultáneamente le insistirá sobre la necesidad de "realizar metas suficientemente elevadas como para lograr el grado de aceptación social que no pudo alcanzar su padre".

Entretanto, "la esposa será probablemente más cálida y acogedora que el marido porque... la conducta en su hogar por parte de un padre privado de estima social, es apta para intensificar la necesidad de que las hijas sean atractivas y serviciales hacia los hombres". Los hijos de las nuevas generaciones experimentarán "un tipo de atención en el hogar propicio a la temprana germinación de sentimientos de autonomía y de superación". "La deposición del respeto social crea fuerzas que, por decirlo así, mueven inexorablemente a las personali- 
dades de un grupo por la pendiente del retraimiento. Pero este movimiento genera fuerzas contrarias que, al ganar impulso con el curso de la corriente, pueden perturbarla, interrumpirla y aun desviarla, hasta que finalmente surge un impulso de creatividad suficiente para canalizar el flujo social en nueva dirección."

Esta creatividad se manifestará en la búsqueda de una nueva identidad, al tiempo que desarrollará nuevos valores. El joven de las siguientes generaciones "podrá identificar individuos o grupos que no lo amenazan y que sin embargo tienen un poder o una posición reconocida por el grupo hostil, como también un papel social que a él mismo no le está vedado. Si este joven percibe la posibilidad de demostrar sus méritos asumiendo los valores y la forma de vida de esos grupos, estará abordando una solución muy prometedora". "En Colombia, las proezas tecnológicas de los grupos innovadores de países extranjeros cumplieron este fin. Esas proezas constituian una extensión de las ocupaciones manuales de los antioqueños, quienes al apropiarse de ellas, ostentaban precisamente los mismos valores de los grupos colombianos superiores, lo que hacía posible llegar a tener mejor posición económica que la de estos últimos." En esta forma quedaba abierta la vía propicia para la adopción de actitudes, hábitos y valores conducentes al desarrollo económico.

Después de haber trazado este marco teórico general, Hagen examinó varios casos de transición socioeconómica, tales como los de Inglaterra, con su grupo minoritario de inconformistas religiosos; 0 el del Japón, con su dinámica de clases entre samurais, ricos mercaderes y campesinos; o el de los núcleos urbanos de Indonesia, con la revolución de las castas superiores; o el de Antioquia, con sus desposeídos campesinos y sucios mineros escarnecidos por la leyenda de su ancestro judío y de su miserable desempeño en las contiendas militares.

La visión teórica de Hagen fue criticada muy severamente por eminentes sociólogos norteamericanos. ${ }^{154} \mathrm{~A}$ este respecto el profesor Hoselitz expresó su opinión de que la confirmación definitiva de la verdad o de la falsedad de la teoría de Hagen tendría que encontrarse en el examen de la evidencia histórica y de su interpretación. En este sentido, el reciente artículo de Safford es muy pertinente y arroja serias dudas sobre el valor explicativo de la teoría de Hagen con respecto al cambio social en Antioquia. ${ }^{155}$ A las anotaciones de Safford podrían agregarse algunos comentarios adicionales.

En primer lugar, deberíamos preguntarnos qué tan intensa ha podido ser la percepción de una supuesta negación del status social antioqueño por parte de los núcleos bogotanos y payaneses en los tiempos coloniales. Si es cierto que existía un grado extraordinario de analfabetismo e incultura; si las comunicaciones entre distintas provincias de la Nueva Granada eran tan limitadas; si en particular los mineros y campesinos vivían en condiciones de excepcional aislamiento, $\mathrm{y}$, si apenas unos pocos comerciantes mantenían contactos con

154 Véase Bert F. Hoselitz, en The American Journat of Sociology, marzo de 1963. También Wilbert E. Moore, en American Sociological Review, abril de 1963.

155 Frank Safford, Significación de los antioqueños..., passim. 
la gente de otras provincias, ¿a través de qué canales pudieron haber invadido las actitudes y los valores del grupo antioqueño aquellos supuestos sentimientos de subordinación social con respecto a otras provincias? Es cierto que los diezmos pagados por los agricultores y hacendados se remitían a Popayán o a Cartagena, pero no se dispone de ninguna evidencia de que tal estado de cosas haya creado una situación de conflicto abierto, en tanto que los documentos históricos ilustran abundantemente diversos tipos de tensiones internas en la sociedad antioqueña. Ejemplos de estas tensiones fueron los levantamientos de los esclavos negros contra sus amos; algunos actos revolucionarios contra las autoridades españolas, el pronunciamiento de los comuneros, que en Antioquia se manifestó y articuló sobre todo en las regiones donde la tierra labrantía era de condiciones de fertilidad desfavorables; el resentimiento de las comunidades urbanas contra una burocracia colonial abusiva, ineficiente y codiciosa, etc.

No resulta inconcebible que algunos rescatantes o arrieros hayan podido informar sobre las condiciones y actitudes prevalecientes en otras provincias, pero no se dispone de evidencia de que aquéllas hubiesen sido relacionadas directa o indirectamente con fenómenos como el alto costo de los víveres o la marcada incidencia del desempleo. En un documento tan importante como el memorial de los Comuneros de Antioquia, los habitantes de tierra fría se quejaban de su desventaja con respecto a los agricultores de tierra templada en Medellín y de las maniobras explotadoras que sufrían a manos de sus abastecedores. En cambio no se hace ninguna referencia a la situación comparativa frente a Bogotá o Popayán. ${ }^{156}$

En las últimas décadas de la Colonia, la situación social de Antioquia era caracterizada por los observadores como quizá la más atrasada dentro del conjunto de provincias de la Nueva Granada, pero sería demasiado simplista dibujar la estructura de la sociedad en términos de un grupo homogéneo unificado por el sentimiento de negación de su status social frente a otras regiones. Comparaciones con la opresión que sufrieron los mercaderes, campesinos y samurais japoneses bajo la hegemonía Tokugawa; o con la percepción mental de la baja nobleza y del común de las gentes británicas en el sentido de que la conducta de los monarcas Plantagenet, del Papa, de los Arzobispos, de la alta nobleza y de los clérigos poderosos indicaba muy poca preocupación por el bienestar público y por los patrones establecidos de moralidad y de decencia, ${ }^{157}$ no parecen llevarnos muy lejos en la comprensión del cambio social antioqueño. Repetimos nuestra opinión de que esta descripción de una estructura social en la Antioquia colonial no deja campo para el estudio de las tensiones internas que se generaron dentro del mismo grupo y que finalmente abrieron campo a un nuevo orden económico y social. Las invasiones de tierras por los colonos, el estado de desvirtual abandono de las grandes concesiones latifundistas, la estratégica posición adquirida por los rescatantes, la liberación espontánea de los negros esclavos, las características locales del levantamiento contra los españoles, etc., son todos aconteci-

156 Francisco Duque Betancur, Historia del Departamento de Antioquia. Medellín, Imprenta Departamental, 1967, pp. 361-362.

157 Hagen, op. cit., p. 271. 
mientos históricos de mucha influencia que quedan forzosamente por fuera del esquema analítico de Hagen.

Un último punto de esta discusión merece ser por lo menos enunciado, con respecto al significado histórico de la teoría de Hagen. ¿Cuándo se hicieron manifiestos en Antioquia los nuevos valores sociales propicios al crecimiento económico? ¿Fue hacia 1850, fecha a partir de la cual el propio Hagen traza los comienzos del cambio social? Si ello es así, ¿cómo se calificarían las manifestaciones de espíritu de empresa que se registraron tan claramente en los años veinte y treinta por parte de la burguesía local? ¿Y qué se diría de los primeros movimientos espontáneos de colonización que aparecieron desde los últimos años del siglo XvIII? ¿Qué significado tendrían las habilidades y prácticas que los rescatantes coloniales desarrollaron con el propósito de derivar los mayores beneficios posibles de los arriesgados trueques y fiados a su clientela? ¿Por qué las zonas de frontera del siglo xvIrr mostraron ser más dinámicas que las demás en cuanto al ejercicio del comercio, la minería y el laboreo agrícola? Resulta prácticamente imposible considerar estas preguntas dentro del marco teórico de Hagen, puesto que él ignoró completamente el movimiento colonizador, sostuvo que la minería mantuvo su estructura colonial hasta 1900 y no prestó atención suficiente a las condiciones de la clase comerciante.

\section{d) El examen sociológico de Havens}

Hace pocos años el sociólogo A. Eugene Havens publicó una monografía sobre la estructura y la dinámica social de Támesis, comunidad rural situada en el suroeste de Antioquia y colonizada durante la segunda mitad del siglo xIx. Esta monografía aportó una información empírica y un análisis de mucho valor para la comprensión de la dinámica de la tenencia de tierras y de su impacto sobre la estructura y el cambio social de aquella localidad. De particular interés son las comparaciones entre formas alternativas de organización de la agricultura y el examen del significado que las asociaciones voluntarias han tenido sobre los programas de acción comunal. ${ }^{158}$

Por otra parte, Havens sugiere una interpretación histórica del movimiento colonizador antioqueño durante el siglo XIX que no quedó suficientemente elaborada en su análisis. El autor atribuye la forma peculiar de poblamiento rural a cuatro factores interdependientes. EI primero era la disponibilidad de tierras fértiles accesibles libremente o a bajo costo. El segundo, la elevada tasa de crecimiento demográfico. El tercero, la alta valoración social que tenían la propiedad agraria y el trabajo independiente. El cuarto, el espíritu de independencia, la capacidad de trabajo y en general el ethos aventurero, diligente y astuto de los antioqueños..$^{\text {I59 }}$

Pero después de haber seleccionado los elementos de su modelo y de bosquejar las características de cada uno de ellos, Havens dice muy poco sobre las relaciones que ligaron entre sí aquellos elementos, 
o sobre el marco institucional y la estructura socioeconómica que concedieron significado dinámico a cada uno de los factores explicativos. Por esta razón no parece muy adecuada la estructura analítica de Havens para clarificar el intrigante caso de desarrollo económico antioqueño. Abstraído de un contexto básico que los relacionara unos con otros, ninguno de esos cuatro factores, ni siquiera su suma, nos coloca en posición de penetrar suficientemente en el problema. En particular, la introducción del tercer factor resulta casi un intento tautológico de llenar el vacío dejado por los otros tres elementos.

Para apreciar mejor el significado de este vacío, examinemos, por ejemplo, el primer factor que aparece en la interpretación de Havens. La tierra fértil había existido en Antioquia mucho antes del período de colonización y, en términos físicos, era mucho más abundante y de fácil cultivo que la de otras partes de Colombia. Como lo dijo alguna vez Arthur Lewis, "todo país del mundo ha tenido tierras de frontera a lo largo de sus milenios de historia, pero han sido extremadamente pocos aquellos cuyas fronteras han jugado un papel significativo en el proceso de crecimiento económico". ${ }^{160}$

$\mathrm{Ni}$ tampoco la abundancia de tierra en combinación con un robusto crecimiento demográfico han sido suficientes en otras circunstancias para romper las instituciones latifundistas. Si en Antioquia la estructura de poder de la sociedad hubiese estado centrada en unos pocos terratenientes de tipo tradicional; si el concesionario territorial hubiese sido una personalidad sedentaria en vez de un minero inquieto; si no se hubiesen interpuesto núcleos humanos independientes cuyos rendimientos en la minería se veían afectados por el alto costo de las subsistencias; y si, por último, no hubiese pasado el control político local a manos de una élite burguesa, muy posiblemente la presión demográfica sobre los recursos naturales hubiese sido resuelta por medio de la expansión horizontal del sistema agrario tradicional, tal como ha ocurrido por ejemplo durante este siglo en el nordeste del Brasil.

Otro aspecto del análisis de Havens que no es posible pasar por alto es el del desarrollo demográfico en la frontera antioqueña durante el siglo XIX. El autor sostiene que la inmigración proveniente de otras provincias representaba una gran parte del crecimiento de la población antioqueña durante aquel período, y que esa inmigración constituyó un factor condicionante de la fuerza propia de la corriente colonizadora. Es ésta en realidad una hipótesis novedosa que merece una exploración a fondo, pues en realidad algunas fuentes históricas comentan el caso de comerciantes y hacendados que llegaron a Antioquia en esa época. Pero ningún historiador ni observador de los fenómenos sociales diferente del propio Havens ha llegado a sugerir que estos movimientos hayan alcanzado proporciones demográficas de significación, por lo menos en lo que respecta al territorio que se conoció con el nombre de estado de Antioquia durante casi todo el siglo xIx.

Un análisis muy preliminar de la hipótesis de Havens nos hace pensar que su evidencia es poco convincente. Por una parte, parece estar basada implícitamente en la creencia de que el ritmo de crecimiento

160 Arthur W. Lewis, The Theory of Economic Growth, Londres, Unwin University Books, 1955, p. 152. 
de la población antioqueña fue en esa época demasiado fuerte como para poder ser explicado exclusivamente en términos de un incremento vegetativo. Pero no es difícil demostrar, mediante el análisis demográfico, que una población cerrada con características de nupcialidad precoz, de fecundidad marital biológica y aun de un nivel de mortalidad muy alto, puede fácilmente duplicarse en un período de veinticinco años. En cuanto al período de fines del siglo xvIrI, en el cual se observó por primera vez este tipo de crecimiento de la población, debe agregarse que correspondió a la apertura de la corriente colonizadora, cuya documentación histórica fue elaborada con gran cuidado por Parsons. En su obra fueron trazados muy detenidamente los orígenes de los primeros grupos humanos que fundaron y colonizaron a Sonsón, Abejorral, Aguadas y Pácora, sin que se haya hecho referencia a inmigrantes provenientes de otras provincias.

De otro lado, Havens apoya su hipótesis en una crónica histórica sobre la colonización y fundación de El Líbano, población tolimense a donde llegaron las primeras olas de inmigrantes antioqueños hacia 1860, a las cuales se unió luego un contingente adicional de personas de otras partes del país. ${ }^{161}$ Leyendo esa crónica de Eduardo Santa, se tiene la impresión de que la segunda ola de inmigrantes a El Líbano no tuvo mucha significación antes de pasados treinta años después de la primera, así que no afecta las cifras estimadas sobre la población de origen antioqueño, de las cuales se dedujo la ya mencionada tasa de crecimiento. Además, la localización de EI Líbano, en la vertiente oriental de la cordillera central, debe tenerse en cuenta antes de generalizar las condiciones de su colonización a las del resto de las regiones hacia donde se desplazó la población antioqueña. Esto, porque El Líbano estaba más cerca y tenía más contactos con gentes de otras provincias diferentes de Antioquia, particularmente en lo que se refiere a aquellos grupos que fueron tan afectados en el Tolima después del colapso de las economías del tabaco y del añil. 